\title{
PANYA
}

\section{Economies of Deception and the Discontinuities of Indentured Labour Recruitment and the Slave Trade, Nigeria and Fernando Pó, 1890s-1940s}

\author{
ENRIQUE MARTINO
}

ABSTRACT: In the first half of the twentieth century, most of Fernando Pó's contract workers came from societies in southeastern Nigeria which had been heavily impacted by the transatlantic and internal slave trades. These contract workers were recruited by a new generation of labor recruiters, dispatched covertly by Spanish imperial employers, through a form of kidnapping known as panya. Panya was the largest labor smuggling and trafficking network in colonial West Africa, bringing tens of thousands of migrants to long and obligatory contracts on Fernando Pó. In contrast to scholars who have interpreted this history as a holdover from the pre-colonial period, this article argues that panya arose from the contractual order of Spanish imperial rule. Extensive archival research reveals the voices of those caught in the warp of post-abolition colonial labor regimes, in order to rethink the passage from the pre-colonial slave trade to imperialism within West African history. Using a series of vivid and precise petitions submitted by those who found themselves on the island of Fernando Pó, the article shows how these sources contain the potential to reconceptualize the disjunctures between enslavement in the slave trade and the recruitment of contract labor.

Enrique Martino (enrique.martino@gmail.com) received his PhD from Humboldt University Berlin in 2016. His published articles include "Dash-Peonage: The Contradictions of Debt Bondage on the Colonial Plantations of Fernando Pó," in Africa; "Clandestine Recruitment Networks in the Bight of Biafra," in International Review of Social History; and "Open Sourcing the Colonial Archive," in History in Africa. 


\section{Introduction}

In Nigeria, across various languages, panya (pánà) is the colloquial name for Bioko, formerly the Spanish colony of Fernando Pó. In West Africa during the nineteenth century, the noun "Panyer" meant "a Spaniard," from the pidgin rendering of España. In Igbo areas, Ugo Nwokeji says, "up to today, the word panya in Igbo folklore refers to forceful removal to the unknown." The same is true in Ibibio, though I would add the important qualification that "force" in panya stresses a series of social and physical forces that keep someone from coming back rather than the act of violent "seizure" which in West Africa in the pre-colonial period was referred to as being panyarred. ${ }^{1}$

Panya and panyarring have different etymologies, but there was a mutual layering and transformation of both terms in twentieth-century eastern Nigeria, when the meaning of panyarring — the "seizing" of free people "by force or fraud" as used by "both Whites and Blacks" in precolonial Calabar $^{2}$ - was reinterpreted in light of new experiences with the colonial labor market of Fernando Pó. In Southern Nigeria, by the early twentieth century panya had become a term to refer to a range of relationships linking a class of illicit commercial intermediaries with a host of impoverished jobseekers from specific regions in Nigeria. On the Cross River Delta in the mid twentieth century, panya was "a term usually used only by smugglers;" it was also a term used to refer to them, connoting "mischievousness" and "hustlers." In Igbo areas, its meaning was linked to ahia panya, or "panya trade," meaning smuggling, but also faulty and unsound commodity exchange. ${ }^{3}$ The toponym Panya, in addition to being an actual buying and selling hub for canoe-deploying smugglers, was also a popular conceptual plateau, because "no one receives news directly from anyone who goes to [work in] Fernando Po. Rumours of death, imprisonment and ill-treatment are current." It was a figurative but "hard" place, where "misfits" and troublesome children and subordinates "feared" being sent—-threats made by superiors, usually in a facetious manner.

But many people did in fact disappear to panya, and if they came back at all, they returned many years later, more often than not "empty handed" with "nothing to show" in terms of "achievements" and gains- the meaning of the expression having come back "from panya." Panya was a layered and localized reflection of the violence and language of capitalism in an imperial labor market in West Africa, of the experiences of commodified mobilities and the opaque commercial mediators of those mobilities. This article explores those mobilities through an examination of the labor recruitment techniques that were used to informally arrange the crossborder migration of Nigerians to Fernando Pó. 
An account of the pattern and effectivity of its trajectories is important, not least because this migration is one of the largest undertaken in colonial African history. If in 1938 the "influx of Nigerian boys into Fernando Po" was "undoubtedly on the increase," a year later recruiters operating out of eastern Nigeria had brought over an unprecedented and never again surpassed " 12000 Nigerian labourers and all of them were smuggled in canoes across the sea." Illegal migration peaked during the decade of war encompassing the Spanish Civil War and World War II; during these years, contemporaries spoke of workers being "virtually 'press-ganged' for Fernando Po."7 As David Pratten has observed, "fears" of a "revival of the slave trade" developed "on a new axis during the 1930s with the dramatic increase in migration of Nigerian workers [to] Fernando Po off the coast of Calabar." The idea of "revival" is relayed not only allegorically and polemically in the only two existing empirical academic works; both Henderson Tapela and Akinjide Osuntokun speak of a twentieth century "Nigeria-Fernando Po 'middle passage." "9 Early in 1939, Okon Archibong, a future anti-colonial political activist, let the chief provincial administrator at Calabar know of the "unrest that is existing in your Province" due to the revival of "a slavish act [that] had been absent from this Province for many years. ${ }^{10}$ British District Officers (DO) throughout the Eastern Provinces had been receiving many "complaints asking for information as to absent relatives in the island and alleging 'slave dealing.'" To the families and clan chiefs, it seemed obvious where to point fingers: the "recruiting of labour is largely carried out by the Efiks and people living in the area of the Cross River estuary."11

Panya labor smuggling was portrayed differently by those who experienced it when compared to their family members, literate members of a vocal public, and the British colonial administration. The latter, for example, declared that the "traffic of labour to the Spanish Guinea falls little short of "blackbirding'." 12 In the early 1950s a British Vice Consul on the island wrote that "for the last fifteen years and even before that" Fernando Pó was seen as a "source of income by [those] who enriched themselves by shangaing unsuspecting Eastern Nigerians over here and selling them as labourers." 13 "Blackbirding" and "shanghaiing" were terms for a modality of recruitment in the nineteenth-century colonial Atlantic and Pacific that meant kidnapping for remote off-shore indentures, on board ships or in plantation islands and enclaves. This type of labor usually operated outside affidavit-generating courts, or any other institution that might make a contract in the workers' "home" countries; instead, contracts were almost always forced onto people when they arrived at their final destination. Moreover, the destination itself was usually unclear, and even when it was known, recruits were "seriously misled by unscrupulous recruiters" about 
their "duties, and compensation." ${ }^{14}$ In the 1930s Major Orde-Brown, a prolific advisor on African labor matters to the British colonial secretary, pondered the principal modus operandi of Fernando Pós recruiters, the "native touts who deceive" migrant workers "as to the nature and conditions of the work." Uncertain as to what these tangles of (mis)information would mean for the character of this movement, he concluded that the "decoying of labourers out of [Nigeria] may well be little short of slavery." In light of the numbers of Nigerians going to Fernando Pó, Orde-Brown ended up assuming that the "majority of people seeking work are probably doing so voluntarily," because of the fact that the majority of people who went to $\mathrm{pa}$ nya did not consider themselves enslaved at the point of recruitment. His hesitation on both fronts - "little short" and "probably" - is symptomatic of the double bind of this "free and unfree" labor movement. ${ }^{15}$

The slave trade conceptually contaminated its supposed opposite-free migrant contract labor-through the revelations and scandals of recruitment techniques, referred to skeptically in the revisionist literature on indentured labor as the "deception argument." A generation of historians in the 1980s, known by detractors as the "Modernization School, sometimes also indicated as the Imperialist or Colonial Group," turned the fact that "most indentured migrants left their homes voluntarily" with "hopes of better conditions and opportunities" into a realization of migrants' desires, an expression of their will, and a manifestation of capitalist ideology. ${ }^{16}$ More recent accounts of indentured labor have continued to circumscribe the possibility that indenture was "founded on duplicity." While aware of the "persisting evidence of fraud in indentured recruitment," some authors turn "specific" instances of deception usually "related to destination" into a minor detail ${ }^{17}$ Nonetheless, even those scholars who are cautious about representing indentured migration within the rhetoric of unfreedom vindicate the foundational insight of Hugh Tinker's influential 1974 book on indenture, A New System of Slavery, namely that "'fraudulent statements [and] false pretences' " were constitutive of the world of recruiters who mastered the art of presenting a "picture of what was to come which was often distant from reality."18 On Fernando Pó both those who experienced their displacement as a "willing" response to a need, as well as those were "drawn to a new land by the better-than-factual stories" - all went side by side on the same canoes, "smuggled across the waters in the Bight of Biafra," to the same place: panya. ${ }^{19}$

In the wider literature on unfree labor, the "duplicitous inducements of indentured servitude" are sometimes analytically placed uneasily alongside imperial naval impressment surges and even the panyarring techniques of the West African slave trade. ${ }^{20}$ Monica Schuler has written that 
the recruitment in Sierra Leone and the Windward coast in the 1840s for indentures in British and French Guiana "combined the recruiting techniques of the African slave trade with the old European bond servant traffic." ${ }^{21}$ Marina Carter takes a less holistic view and argues that recruitment in the Bay of Bengal for Mauritius was "closer to white indentured servitude than to the system of slavery which had immediately preceded it."22 This is an apt contrast, because historians of early modern "white indentured servants" have empirically revised the classic accounts and imaginaries of the so-called "free-willers"- of restless freedom and greener pasturesto show how the "majority of indentured servants recruited in London were recruited illicitly, although they were mainly trepanned by the spirits rather than kidnapped by force."23 The old and new literature on indenture has provided abundant examples of the creative and fiercely "consistent" ways in which those forced or inclined to sell their labor in a labor market would be "deliberately deceived about their real destination." ${ }^{24}$ It is important here to understand "destination" not only as a simple geographic direction but also as a conceptual location in the division of labor, because those who were promised acceptable jobs - such as agricultural work in Nigeria, or desirable placements as trading assistants, clerks and drivers in either Nigeria or Fernando Pó-ended up in a type of indentured plantation labor that was foreign in Nigeria.

The British colonization of Nigeria was overtly justified not only "to suppress the slave trade" but also "to prevent its revival under the guise of contract labour." 25 The Fernando Pó-Nigeria connection during the first half of the twentieth century is quite peculiar, because both African recruiters in Nigeria and the Spanish imperial state and a mix of both African and European employers on the island proved to be immune to the interventionism of British humanitarian imperialism. Panya does not fold neatly into the so-called "guise of contracts" literature, a term often used in African history to describe state-sanctioned indentures, apprenticeships or engagé schemes after the abolition of slavery, when many tens of thousands of freed captives or new slaves were signed up after arriving at various port towns in West, Central and East Africa through former slave supply routes. ${ }^{26}$ Nor was Fernando Pó analogous to São Tomé, where up until the early twentieth century, those enslaved in the Bié plateau in Angola "continued to be imported, bought, and sold under the guise of contract labor" and kept in perpetuity on the plantations. ${ }^{27}$ Nor is the relationship between Fernando Pó and Nigeria akin to the one set up between Fernando Pó and Liberia between 1914 and 1930, when about 10,000 "indigenous peoples were impressed as contract labour" by a small group of senators who did not need to "deceive" anyone. Instead they deployed the armed 
forces of the state to drive recruitment-and assure workers' return-after two years of work in "Fernando Po under the guise of contract labor."

Even though panya recruitment was a slaving genre of "kidnapping and smuggling" that persisted in colonial Nigeria along existing supply networks, it cannot be considered the result of inertia from the precolonial period, subsisting only where "old elites" preserving an "old older" "survived." ${ }^{29}$ Fernando Pó's recruiters were initially drawn from groups who had previously had a hand in organizing (and abolishing) the Atlantic and internal slave trade in West Africa, such as Aguda or Afro-Brazilians and Sierra Leonean Creoles. The majority of recruiters were Efik from Calabar Province, particularly those from Henshaw Town settlements in Oron, and so-called "Cross River Igbo," Abam, Abriba and Aro "resident stranger" merchants with links to Calabar and other smaller waterside trading towns throughout the Eastern Provinces. ${ }^{30}$ But decades after abolition, and with imperial rule firmly cemented in Nigeria, a new generation of recruiters regrouped under the new structural templates provided by Spanish imperial rule, and used this new conjuncture to improvise a radical discontinuity in their technique. The Fernando Pó labor traffic was a spike of a defunct repertoire of the earlier Atlantic world, and of the post-abolition Indian and Pacific worlds, an admixture reaching back and forth across continents rather than unfolding along some anachronistic niche or trait persisting into the colonial period.

The sole area of operation for the "touts" who fuelled the trade of workers to Fernando Pó was the "field"; their only job was to constantly bring in batches of new recruits. Touts were mostly strangers, semi-anonymous in their commercial relation with both capital and labor, and delinked from the colonial state. They were heterogeneous, discontinuous and unrelated. Their viability and strategy relied to a high degree on their individual histories and their capacities to deploy promises within wider structural asymmetries. There were never more than a hundred recruiters at any one time, even during the crescendo in the late 1930s; they were not organized by whom their grandparents were or how the census grouped them. Those involved in the recruiting bloom were not a coherent group reproducing an existing status, nor did they form a class. They were not headmen, "bossboys" or "gangmasters" who supervised contracted laborers throughout their journey and at the worksite itself. ${ }^{31}$ They were not "friends and relatives," as emphasized in much recent literature on indenture and postindenture labor migrations. The odd and variable presence of an uncle, friend or community leader, whether as helpful guide and sponsor or as a receiver of commissions, does not do much to move beyond the wellworn dichotomy of free and unfree labor, because it was still others, mostly 
touts and their associates (who received shares of their commissions) who organized the logistics of movements; moreover, still others, and more often than not state actors, were the ones who set the parameters for the exploitative conditions that workers faced upon their arrival. ${ }^{32}$ The frame of ethnicity and kinship in the study of indenture is the gesture of an impasse, a non-confrontation with the paradox of agency, a bypassing of the contradictions and mutuality that constitutes the relationship between force and choice.

There was no direct continuity with the recruitment techniques of the slave trade, although this argument was made by contemporary observers, who wrote that laborers for the "large European-owned estates" were secured on the "mainland, often by methods reminiscent of old slave days." ${ }^{33}$ A claim to continuity has also been made by scholars; Henderson Tapela has argued that illegal recruitment "began to take the character of the slave raiding of former days. Unwary travelers were kidnapped and canoepaddled from the ports of Eket, Oron and Calabar," ${ }^{34}$ while William Gervase Clarence-Smith has claimed that the shipment of laborers to Fernando Pó was "akin to a slave trade." 35 To be sure, these arguments have some validity, but they need to be stretched, inverted and specified. If the fifteenth century witnessed the clear beginning of a commercialized system across the island- and river-based trading networks of the Gulf of Guinea, geared towards importing enslaved Africans onto colonial worksites, it was on Fernando Pó that this system met its unnoticed and confused end in the twentieth century. ${ }^{36}$ This did not happen in any linear way; to the contrary, it happened through layering and fission, in bursts and quick reversals.

\section{Fernando Pó's Drift in the Gulf of Guinea}

With recruitment techniques for panya there was no cycle, no circular migration, no equilibrium. Instead, there was a constant drift of recruiters across the entirety of the Gulf of Guinea, from west to south from the 1880 s on, and internally in Nigeria itself, where by the late 1940s only a large handful of "illegal recruiters [were] still operating in the northern half" of the Eastern Provinces "where the people are more ignorant and where they can get victims by promising them work in Port Harcourt or Calabar." ${ }^{77}$ "From the beginning of the plantations Spanish planters surreptitiously recruited labour from the coastal areas of Nigeria as well as other parts of the West African coast," though only in the 1930s did they fully deploy "an elaborate recruiting machinery to tap labour from south eastern Nigeria." ${ }^{38}$ The economies of deception created a pattern of shifting incursions within recruitment that was only exhausted after half a century. 
The dynamics of recruitment changed in the late 1940s when the planters' labor demands, which had been rising over the first half of the twentieth century from 1,000 to 10,000 laborers a year, was met directly by the British and later the Nigerian state through a top-down and centralized "labour agency." The 1942 "treaty" permitted an association of Spanish planters to pay licensed recruiters small commissions, to construct a large depot in a converted military barracks in Calabar, and to send a dedicated steamship to make bi-monthly pick-ups. ${ }^{39}$

In the late nineteenth century, cacao exporting plantations had been single-handedly set up by the Fernandinos, the "black capitalists" studied by Ibrahim Sundiata, Martin Lynn and W.G. Clarence-Smith, who themselves or whose parents had formerly been slaves. Fernandinos had mainly come from Freetown, hired by the British merchants and British administrators on the island when it was in their possession earlier in the nineteenth century, or else from Cuba, on the offer of eventual manumission after they took up a contract in the 1860s, when the Spanish state took over Bioko. ${ }^{40}$ Ambitious Fernandinos, such as William Allen Vivour, paved the way for the plantation boom of the 1880s. Vivour himself quickly became the largest planter on the island and employed one hundred laborers, whom he recruited mostly with the help of "two Bassa-people stationed on the coast." ${ }^{41}$ To get workers, this new generation of creole planters and recruiters traversed whatever port towns were connected by steamer, anywhere where "free immigrants" or "slaves escaping their servitude" had "flooded" the "coastal towns," including Accra and Loango, but especially Lagos and Freetown, both of which were becoming a type of "floating" "labour reserve for all of West Africa." 42 This confluence of labor in the coastal trading towns and the more flexible relations that it created "seemed to have blunted somewhat the distinctions between slave, indentured servant, pawn and free labourer," and by the 1890s "slaving, brigandage, panyarring and pawnship became fused in disconcerting ways." ${ }^{33}$

In 1900 there were about a thousand Liberians and another thousand British West Africans from Sierra Leone and Nigeria who were working as braceros (contract laborers) on Fernando Pó ${ }^{44}$ This shift occurred because the principal free labor force in the Gulf of Guinea, the Kru of Liberia, described by colonial employers during the peak of indenture as "the Chinese of West Africa," "were no longer going to Fernando Pó as laborers. ${ }^{45}$ When the British Consul in Spanish Fernando Pó, Richard Burton, had earlier passed through Cape Palmes in eastern Liberia to enlist workers he "failed in recruiting men." "Nanny [Fernando] Po' was a word of fear to the Krumen; they had been made to work in gardens and on the roads" even though they were promised work as sailors, stevedores or stewards, 
and "some of them had been engaged for one year, not two, and had been kept for three." Hearing Burton's fellow travelers on the steamer speak "a few words of Spanish," they deemed him to be "'a Panyer' [a Spaniard], and resolutely refused, with characteristic independence, to accompany" him. ${ }^{46}$ Fernando Pó consistently had a terrible reputation, so that with the departure of braceros after every round of the contracts lasting between 2-8 years, a new generation of workers came-but always from somewhere else. Touts displaced themselves in waves; a patchwork of ever new fringes emerged, where touts would add ever more elaborate fabrications and false guarantees to the repertoire of their recruiting techniques.

A British Vice Consul traced Fernando Pó's "first" Nigerian labor tout to one Aguda man, named Bernadino José Reis, from Brazil House in Lagos island. In the 1890s, Reis began "importing Yoruba labour" from Lagos and

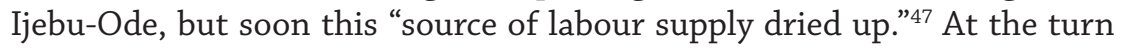
of the century, 450 laborers, most of whom Reis recruited, went on strike, and "marched to the Governors house in Santa Isabel with machetes in hand and refused to return to the plantations." They were met "with guards from the navy who rushed down from the jetty" and the protesters were beaten and deported without their due pay. ${ }^{48}$ After what the Spanish called the "uprising of the Lagosians" the British embargoed labor migration to Spanish Guinea. The prohibition was only partially enforced, and it became quickly "evident that a considerable unchecked traffic in illegally recruited native laborers of British nationality destined chiefly for the plantations of Fernando Po" was being carried out in various port towns in the Gulf of Guinea. Indeed, some of the principal recipients of this illicitly recruited labor were British cocoa exporting houses in Santa Isabel, such as the John Holt company, who "pay 5 pounds for each 'boy' landed," who they then informally lent or rented to various small farmers on the island in exchange for their cocoa. ${ }^{49}$

Reis himself kept recruiting for decades, in different places and targeting different categories of people. In the 1910s, someone accused Reis and a new associate, another "Lagos man" by the name of Thompson, of going "to Bonny and Warri to take little children to sell at Fernando Po. They have sold lots already." Reis and Thompson had a variety of liaisons, as they would hire canoes to get to Rio del Rey in the German Cameroons and then make the crossing to Fernando Pó. ${ }^{50}$ Other recruiters were operating simultaneously or followed in their steps in different places. Calabar's first large scale recruiter in the twentieth century was Ekpenyon John Boko, from the Cobham family in Duke Town, who was "suspected of inducing boys to leave Calabar for Fernando Po without either obtaining the consent of the head of their House, or entering into a proper contract of service." ${ }^{11} \mathrm{He}$ 
had been taking advantage of the rising number of deserters and the newly autonomous job-seekers generated by the abolition of slavery in Nigeria in 1901 and the subsequent introduction of the House Rule ordinance, under which former "slaves," now called servants, were obliged to render tributary service labor to their Efik masters. The rate of flight was so high that even the "most important Chief[s]" found it "difficult to secure enough labour for their trade canoes." 52 Dozens of letters reached the Governor in Santa Isabel from a demoted Efik aristocracy, now classified as "chiefs," such as from Abassi Ita of Duke House, asking about "the whereabouts of his runaway boys." The Spanish Governor happily ignored all of them and pointed the finger back "at the slavery being condoned by the English, who expect us to return these men who left their region freely." ${ }^{33}$ Between the 1910s and early 1930s, most braceros were either recruited by the Liberian state or by the Spanish state, or by recruiters in Rio Muni, Cameroon and Gabon through separate, usually much more violent, recruiting assemblages. However, by 1935, the majority of "the braceros who arrive in our colony [were] all coming from Calabar," and from this point on the majority of the islands' inhabitants (including the large immigrant community of traders, smugglers, skilled and self-employed workers and their families) were Nigerian. ${ }^{54}$

"By far the greater number of Cross River people who migrated to seek employment" abroad ended up on the plantations in Fernando Po. Yet "an Igbo saying has it that "no one who was comfortable at home ever opted for Fernando Po." 55 Extensive migration to the towns in Eastern Nigeria was kick-started in the late 1920s, when the British introduced the poll tax. People moved to "escape tax," "definitely to escape tax," wrote a District Officer in 1930. The sudden tax obligation of 7 shillings was often paid out in bulk to district commissioners by appointed chiefs who were paid their wages in pounds; for those who suddenly found themselves debtors, interest quickly accumulated up to $£ 3$, and they would be "summoned for this amount and they place[d] themselves in bondage" to creditors and chiefs who "take all our money," as a resident of Aba in 1930 put it, adding "on account of the tax and various other matters people have pawned themselves." ${ }^{.6}$ In the 1930s, as with previous generations, many of those entering this new labor market were escaping other forms of unfree labor generated under colonial rule. In the districts of Owerri, Aba, and Bende, where a majority of migrants came from in the 1940s, the selling and pledging of land became unusually common. In the "hope of gathering the first installment to pay for a bicycle or a [palm oil] press," land pledges were being accepted as a "security for a debt." Land could be seized by creditors for failing to pay back loans and high interests rates, something which had "driven many away from farming to seek their fortunes abroad." ${ }^{7}$ 
The wages and conditions in Fernando Pó made the island attractive only to the "miserly situated labour" in Nigeria; most migrants arrived "completely destitute and penniless," and many "had never worked before," at least in the sense of the word as it was used by European administrators. They were drawn from the ranks of those who for various reasons could not find work in Nigeria, such as absent social and kin relations, who generally facilitated money-making opportunities and provided the sums of money needed to pay the initial fees that would secure placements, training and apprenticeships in Nigeria itself. Some also had their own reasons for "a hasty exit from Nigeria, e.g. debts, taxes unpaid, family disputes." ${ }^{58}$ The "evil" reputation of Fernando Pó almost always preceded the spread of the "illegal recruiters in the widely scattered areas of recruitment." ${ }^{\text {" Fernando }}$ Pó and its recruiters quickly "gained a very unsavoury reputation" after "cases of kidnapping were brought to light," but colonial officials assumed they met with quite "some success," "partly because the very dense population in Onitsha and Owerri Provinces had created a class of landless peasants, who were compelled to turn to wage earning for a livelihood." 60 But on closer investigation, it was clear to those doing the investigative groundwork that only "through such agencies as may exist in Calabar," that is "through the instrumentality of a 'recruiting agent," " was it possible for anyone to find their way into the island's plantation contracts. ${ }^{61}$

\section{Economies of Deception, 1930s-1940s}

Labor migration to Fernando Pó was not created through violence, which uprooted people from their land; people wanted to or needed to be on the move, just not necessarily towards the places and under the conditions they ended up in. Touts did not induct people into capitalist labor systems through the conduits of slaving violence, but rather through language alone, through a quasi-kidnapping based on misinformation as to the destination or the type of work. Many Nigerians, tens of thousands, ended up forcibly contracted to Fernando Pós planters, and considered their temporary fate to be a type of slavery-which in effect it was, just for a delimited period. Recruiters were not armed; they did not purchase or redeem "existing" slaves or raid for new ones, "as it is unthinkable that nations like France and England, from whose colonies our labor power arrives, would have allowed us to employ procedures that require violence and coercion" - as a Spanish diplomat said in defending his colony at the International Labor Organization in $1935 .{ }^{62}$ A Spanish petty functionary on the island explained the modus operandi: "deceitful methods operate in la recluta [recruitment] and this is well known by all, because if it wasn't for 
the manipulation of appearances, the indigenas [natives] would not come to work for us." ${ }^{63}$ Another settler said that while it was "not always necessary to employ cunning and trickery and other despicable procedures, at least half" were set up this way ${ }^{64}$ This is as good an estimate as any, as various surveys confirm that at least half of Nigerian recruits in this period "claimed ignorance of knowing that they were being taken to work in the Spanish Cocoa plantations." 65

Touts armed themselves with varying degrees of deception, creativity, theatrics, and the most intimate of illicit relations, betrayal. Their peaceful "linguistic" techniques were made up of important omissions and plenty of embellishments, and used to solicit an initially affirmative response. Unlicensed and unregulated labor recruiting in Nigeria was banned, not because it was restrictive or necessarily unfree, but because it was considered "too free" and disinhibited, beyond the laws of exchange in territories of excess. While British District Officers were generally pleased to see the "acceleration of the drift," shorthand for the emergence of a "pool of surplus labour" arising from the "tendency of young men to drift to centers of semi industrial employment," they worried about the "drain of labour to foreign possessions," because this "drift" was imagined to come from both the "avarice" of recruiters and the promiscuous expectations of the "uneducated young man, in search of easy money." ${ }^{66}$ The recruiters used "lies, deceit, and stealth to get labour from Nigeria," said a journalist in the Nigerian Eastern Mail during the outpouring of the reading and writing public in $1939 .{ }^{67}$ Scholars who have seen the sources say that "recruiters resorted to deception to entice young men to leave their homes." Recruiters "were in the habit of making exaggerated promises [and] of hiding the fact that the labourers were going to Fernando Po." The "sweet-tongued recruiter convinced his victims that Fernando Po was a haven of wealth easily extracted from apprenticeships, shop-assistantships and domestic stewardships." ${ }^{88}$ The recruit was "stuffed with sufficient falsehoods to induce him to accompany the recruiter to Fernando Poo or sufficiently far on the journey as to make it impossible for him to turn back when he finds out the truth." ${ }^{\prime 9}$ Touts could operate with a manipulative indifference and a mild kind of sadism, but they wielded no weapons; they simply latched on to people who were already on the move, redirecting the desire of migrant laborers and often leading them toward failed hopes and an unwilling fate on Fernando Pó's plantations.

Dandeson Green, a Krio or Saro and "veteran Calabar reporter" with pro-colonial credentials, wrote that while "many Nigerian labourers went to Fernando Po of their own accord," a "very considerable number are taken, either by force or with the promise of 'Utopia', by ruthless smugglers 
and illegal native recruiters." ${ }^{.70} \mathrm{~A}$ trader from Lagos said that he came across a group of recruiters who disembarked with a group of unwitting recruits whom they had brought "under the pretext" of being trading assistants who were hired to carry trade goods in and out of the island: "boys whom they have impressed with the notion of FERNANDO PO being an El Dorado for the unemployed and depression in Nigeria and upon their arrival there are made over to some farmers for some inducive amounts of money." ${ }^{11}$ Ruthless peddlers of "utopia": the "chief trouble is caused by the army of recruiters who entice young people away, their story of Fernando Po being a land 'flowing with milk and honey' is, however, true."72 There was indeed a lot of money and accumulated wealth circulating in Fernando Pó. A British missionary in observed in 1938 that Fernando Pó was "so different from anywhere else in West Africa[;] . . it is an amazingly wealthy little island." ${ }^{3}$ Much of the money to be made went to those who "import foreign men to suck dry its honey." 74 For the mix of official and underhand payouts from the Spanish labor officers and from individual planters, the recruiters were "prepared to shangai, trick or, by any method open to them to persuade their country men to come over here, provided that they themselves make a handsome profit out of the deal." 75 The "recruiters at certain seasons asks and gets as much as $£ 15$ per head [with] no questions asked," a sum higher than the wages for a two year contract, and about the same as the annual average income in the Eastern Provinces. ${ }^{76}$ Indeed, it was the "lucrative commissions" which Fernando Pó's recruiters could command that gave their activities, in the eyes of scandalized colonial contemporaries, "the character of a slave trade." These commissions were seen by British colonial officials across the empire as " a reward for extra cunning in inducing coolies [or even as a] compensation for the risk run in unlawfully inducing or compelling them to go." "77

All touts offered a "free ride"; no one paid for their canoe passage to Fernando Pó, there were no tickets, only arrangements and their errant potentials. This made the barrier to emigration non-existent, but recruits wound up paying for their own displacement. The substantial wage advances that was sometimes promised to them went straight into the hands of the recruiters who dropped them off at the Curaduria - the labor office in the capital, Santa Isabel. No one ever saw this advance money (or dash) the first time around; instead, they were met with an obligatory and irrevocable contract, lasting a minimum of two years, earning the monthly equivalent of the sale-price of three large yams a month. On arrival, "the police department takes charge of them and see that they all get employment." Arrangements for commissions were made by "unlawful recruiters mostly" and some "old hands who return with boys to his Master." These mediators "name the 
Farms or masters with whom they will work. These claimants sign for them and the [braceros] are taken to the Curaduria" to receive a copy of their contract. According to J.W. Kicks-Dadzie, an investigative journalist from the Nigerian Daily Times, it was this commission "which most of the labourers resent when they happen to hear of it." ${ }^{\prime 8}$ For "new arrivals," the extent and amount of dashes and commissions handed over to recruiters was often "completed over their heads;" they were "not aware that the tout had made capital out of the recruitment and that the employer has had to pay far more than may appear." ${ }^{\prime 9}$ Canoe passengers "found themselves to their dismay, being disembarked at Santa Isabel (Malabo) and auctioned to waiting plantation owners." 80 The often delayed realization of the exchange of the commission is why a single blow did not need to be thrown by any middleman to consider oneself temporarily enslaved; workers were bound on site and considered themselves to be effectively working almost for nothing.

The recruiters appropriated subjectivity and labor by receiving their commission, a process experienced as a kind of avarice of accumulation at the expense of others. As Ekpe Eyo, a Christian convert from Uyo, who managed to get a letter to his father through the Methodists mission in Fernando Pó, said: "greet Etim Asibong warmly for me for he brought me here to stay here, and went back in peace and earner his money and ate things and live and let me die and suffer." ${ }^{\prime 1}$ An anonymous letter from a laborer contracted in Fernando Pó does not explain how he has was recruited, but only says that "an eket man has brought me here to sell for $7 £$," irrespective of whether he was deceived as to the destination. ${ }^{82}$ An Ibibio petitioner on the island representing a group of imprisoned workers denounced the "traders bringing the people to this country in awfully way" because they were "saying that we were going to Tico or Victoria," on an offer to work in the large British and German plantations in British Cameroons, many of which were "accessibly only by water." There, the laborers were increasingly from Nigeria, who were "for the most part recruited by Efik contractors belonging to Calabar" and were brought "by canoe from Oron." ${ }^{83}$ But for the petitioner, the art of deception was of secondary importance; the realization of what panya meant came only after the contracting had taken place and the commissions had been exchanged. The petition ends with a startling thesis: "I am telling you fact and clearly that [the] canoe-men [are] total selling person to those people [planters] by a great lot of money. Thats why slave is better than us in thousand upon thousand way." ${ }^{4}$

The recruiters carved out for themselves an extraordinary slice of profits, gained through the labor market they were themselves generating. The recruiters' commission was well beyond the costs surrounding their labor of logistics, which covered the ensemble of brokers, paddlers, bribes, and the arrangers upstream and downstream, including chiefs and false 
friends and sub-touts on the island itself. Because of this, "judged solely on the question of motive" - the "thought of nothing else but the prospect of earning the promised commission on the transaction"-recruiters were considered by one newspaper columnist after another "to stand on practically the same footing as the local slave dealers of the early days." 85

Tapela distinguishes between outright abduction and misinformation. The former forms part of the topos of the slave trade and is usually referred to as such in the sources. Such instances seemed to be subdivided into two: the kidnapping of children on the one hand and of literate and educated adults, often professionals, on the other. There "was evidence that children were being stolen and sold to the island of Fernando Po in a manner similar to the kidnappings of the precolonial period," and some of the evidence suggests that such children accompanied some of the better placed migrant laborers to work in their households. ${ }^{86}$ On the other hand, it was quite common that the victims who were "shanghaied from Calabar" and "taken to Fernando Po against their will and arrangement" were actually ordinary passengers and "teachers, traders etc. going on business boarding canoes" which daily left "Oron or Calabar by night." ${ }^{87}$ Rumors of kidnapping saturated anonymous transportation hubs, but people still needed to be on the move. Obligatory transit points became infused with insecurity, alarm, caution and suspicion. If they could avoid it, people did not travel alone or at night. ${ }^{88}$

Victims were accused of being heedless and unmindful, but succumbing to subterfuge is a very subtle and complicated process. Even in areas far from Oron, where people felt less vulnerable, people could be kidnapped on the open water, such as Peter Udo, who reported that as he was "on his way home from a Cameroons plantation" he was told by the "canoe-man" to "change canoes" only to be "transported to Fernando Po" with five others. ${ }^{89}$ The same canoes carried both the misled and the outright kidnapped; for example, in July 1944, on the same canoe was one "schoolboy from Calabar" who boarded it having been promised a job as a trading assistant on the island, "deceived by the canoeman whom he knew." Also on board was "a soldier who had been up country to visit his relations" making the "trip from Oron to Calabar." Both woke up the "next morning on the Island, and [were] sold and contracted."

The official response to all this was muted. Key British officials managed to turn the way to panya into the failing of "simple minded natives" who "have been induced to join the canoes in the expectation of being given a lift downstream, only to find themselves landed in Santa Isabel." ${ }^{90}$ District Officers throughout the Eastern Provinces pithily summarized the spate of inquiries submitted by "relatives worrying over the whereabouts" of their family members who had been "taken away by strangers to work at 
Calabar," but not having "been traced" their "relatives fear that they have been shipped to Fernando Po." Recruiters were shifting further north and west, and everywhere they had been seen "prevailing on youths by specious promises and glowing accounts of conditions obtaining in the plantations near Calabar and in the Cameroons, to accompany them" only to end up being "taken to Santa Isabel." ${ }^{91}$ But it was not that simple; colonial authorities fixated on the narrative that the broker could get away with tricks because of the "gullible" and "ignorant peasants from the Ibo and Ibibio areas," who were being brought over to Fernando by "unscrupulous native "black-birders' who earned a lucrative livelihood by kidnapping" them. ${ }^{92} \mathrm{It}$ is as if they were displacing blame onto the absence of an internalized concept of "due diligence" prior to a transaction.

The fine-grained archival material-hundreds of depositions, letters home, voices from police and press reports - reveal that that each recruitment case or scenario had its own iteration of creative opacity and varying degrees of misinformation rendering "informed" consent technically null and void. Experiences varied, for example: Affiat and a group of his friends were recruited by "one lady in Henshaw-Square at Calabar named Ne Edak" who was "making a great craftiness before she" brought them to a plantation belonging to a Spanish lawyer, Estrada, "the worst farm in the Fernando Poo." ${ }^{93}$ Ekpenyong Etim, a trader from Calabar, who on the island saw "boys came out in quantum" and "was sad when seeing them, because [they] come and die," brought by "those tradders [who] make tradding of boys, [not] only the tradding of goods" and "signed the boys with bad amount of 10/- [wage] in bad farm they died away hopeless." ${ }^{4}$ Akpan Okono, who accompanied his brother who was going anyway to Fernando Pó because he had heard "there was much money and that it would be easy to save up." Okpay Awa, from a village in Bende who "followed his friend Kalu Ukay, who told him he was going to work in Victoria," but Kalu "brought him to Oron and handed him over to the canoe-man Sambo Ekpa." ${ }^{95}$ Bronwson Edem Ekong, of Eket, who had started to trade but "lost his money and became stranded" on the island and contracted himself to a plantation where "tobacco, snuff and free medical treatment" was provided, and who subsequently embarked on a short career as a recruiter until he was arrested in 1938. ${ }^{96}$ Anele Nwosu of Owerri and Elijah Chiolu of Ohoada, who were "at Nwaniba, Uyo, as part-time labourers to U.A.C. [United Africa Company] and at other time as petty traders" when

[o]ne Abriba man advised us to accompany him to Victoria as traders. The two of us conjointly bought 100 yams (£5), two bags crayfish (£1.16/-) and two tins of palm oil (18/-). We all embarked on a canoe at Nwaniba. To our 
surprise the Abriba man (Eni) clandestinely brought us to Fernando Poo and contracted us to work for Aselope at Bispa. ${ }^{97}$

Wilson Bassey, a "probationary Teacher" who in 1944 "resigned due to my aim of joining the army," was on his way to Calabar when the "junior clerk in John Holt Office called Utche deceived me not to join the army" by promising him a clerical job "in the shop" of a merchant in Fernando Pó. In a moment of indecision that he came to regret, and remembering his anxiety during his job search, he confided to the British Consul, whom he petitioned, "as you know an applicants heart is always in a circulation and not steady." Wilson had been in panya, so he realized that once under contract there was no going back, "a matter of no help as I am under contract, I am serving as a labourer in the plantation of Finca el Pino. It is a great pity to me as I am such a great suffering." ${ }^{98}$

For recruitment to oscillate this way required an entire field of colonial power, not just the "exceptional and peculiar gifts of the able recruiter."99 The head-hunter or human resources specialist, in order to deliver results and get their commissions, more often than not, transformed themselves into what were known in Nigeria as "confidence men" or wayoman. ${ }^{100}$ The irregularity and opacity of these recruiters should not be taken as "explanations for the inequities and exploitation surrounding migration," rather, their techniques and infrastructure and resulting suffering were put into play and funded by structural links to the imperial laws that enabled the demand and the conditions of exploitation. ${ }^{101}$

\section{Touts and the State, Nigeria}

Before I demonstrate how the contract itself generated the intensity of recruitment, I will examine one typical case of panya recruitment in fine detail. Late in 1938, the District Officer of Eket went on tour, and at the last town on the road to Oron from Aba, while out on a late evening stroll, his translator, "Mr. J.I. Peter, met a party of 19 Ibo men" marching "on foot to Oron." This party was quiet, they "had removed [their] boots for the night march," but "he overheard [them] grumbling to each other that they could not see why they should be made to travel at night." They had "started out from Aba in a lorry" that morning and at Okopedi they stopped to meet the paddling crew, to plan a rendezvous in "one of the little creeks near Okopedi where canoes will be waiting." Startled and after some commotion, the party was led to the nearby rest house where the DO was staying the night. There he tried to arrest the "only non-Ibo" among them, while remembering being quietly impressed with "George Matthew Offiong, alias 
Asuquo Bassey," whom he described as a "literate, rather smooth-tongued person." Under interrogation "Offiong insisted that he had been sent by 'Mr. H.G. Brown Manager of the Adiabo Plantation," a United Africa Company rubber plantation east of the Cross River near Calabar "to recruit labour." Offiong had "represented to the men" the same story, and by "his own statement" recounted how he had "secured introductions" to "a chief (whose name, the men say, is Abang Chibwu) and by means of those persons recruited 19 men." Before they left Aba, "the men demanded that the conditions of service be given to them in writing," insisting that they "would not have gone unless they had the conditions in writing."

Offiong produced a document; it was indispensable and incriminating, its strength and weakness was that it could be deployed with brazen confidence and meticulously inspected. It was a sheet of paper with the header-typo and all_-"Robber [sic] Plantation Adiabo."” This was a felicitous spelling mistake, both because it is what caught the DO's eye and confirmed his suspicion, and because Offiong, while not a "robber," was a con-artist, almost fully literate, and able to produce or source forged documents. While the DO was "convinced, he was trying to carry [them] away to Fernando Po" he "had no charge against Offiong." There had been no "offence in the nature of deprivation of liberty" as there was "nothing in the Criminal Code to prevent a person inducing another to accompany him under false verbal promises." The DO called it a night and "advised the men" to "keep an eye on" Offiong, and this "they did, and when Offiong tried to go away during the night, they stopped him." The "next morning" Offiong changed his story and tried to persuade the DO that "in fact he was recruiting labour, not for the United Africa Company, but for 'his father's plantation at Akpabuyo near Calabar.' " 102 Michael Offiong was sent to Eket prison-not for beguiling or controlling representations in the minds of others, but for "forgery and uttering false documents." It is not clear how long he was in prison-although it was certainly not for long, because the DO was unaware that he had stumbled on one of the main recruiters, operating since the mid-1930s, with a network of proxies, a delivery crew on the island, and a handful of large Spanish planters as regular clients. ${ }^{103}$ Within a few years of the incident at Okopedi, Michael Offiong, alias Asuquo Bassey, was back in Santa Isabel. He was the biggest recruiter based out of Calabar, with five canoes at his disposal and sixty rowers at his command. With a trail of forgeries and bribed officials in his wake, in a single day in December 1942 he passed on a hundred laborers to the police/labor office/ planter "combine" at Santa Isabel. ${ }^{104}$

For the British, the tout was almost unanimously seen as a "modern successor of the slaver," capable of "any sort of roguery or deceit to cajole 
his victims." Even fascist colonial Spaniards under the Franco regime acknowledged that "veritable slave-traders had been resurging in the twentieth century." 105 The transference of this label nonetheless left the British authorities in a quandary, because they could not intervene through legal means. Touts treaded on fine lines and in legal grey areas; they only became liable to punishment and penalties when they crossed a border out of Nigeria. Even when the British revamped their investigative surveillance and patrols, with a directive to pursue and repress, the border of the state unfolding beyond the customs wharf and check-point outposts was being consistently outmaneuvered. Fernando Pó's touts concealed many things, but not themselves, as they were doing nothing illegal, and so they could tout undisturbed at riverside markets and junctions, on one of the many thousands of canoes that travelled the waterways that fed the Cross River.

While British officials said they were keeping a "strict watch" and "all illegal recruiters against whom evidence exists are prosecuted," they also papered over their own inadequacy by claiming that touts were "skilled in the art of evasion and arrests are rare." 106 Up until 1938 the British "had a motor launch which was used to pursue" these "smugglers of human souls," but due to budget cuts this "service was stopped" for over half a decade, and so, as David Aworawo says, "the illegal traffickers had a field day." 107 During this key spike in the canoe traffic, the "water police" forces were themselves only being "equipped with canoes." In 1939, there were at least sixty canoes going to Fernando Pó on a regular basis. These canoes "generally sailed in convoys," "large convoys of canoes up to 20 in number" that gathered offshore in this formation so that they could disperse in all directions if pursued by the "water police," who "proved too slow to intercept some large sea-going canoes, which were said to have shown a clean set of flashingpaddles to the launch as they escaped." ${ }^{108}$ By the end of World War II, a small sea launch was tossed into the Cross River Delta, but should it "call upon the canoes to stop" practically all "escaped." ${ }^{109}$ Even District Officers looked on as some of the "great canoes of the Niger and Cross River deltas" that could be up to "seventy feet long" and carry up to hundred people including "pull-a-boys, or paddlers" "put out to open sea and make the coasts of Fernando Po, at its nearest ninety miles away."110

Colonial authorities struggled to follow and understand the organization of people who were doing the smuggling; unless they caught someone red-handed on canoes near Fernando Pó, they met with little success when implementing criminalization as policy. British justice found that "illegal recruitment" was "extremely difficult to prove." 111 Leads sent in by family members who received letters from relatives in Fernando Pó did not result in convictions until proof could be mobilized in the local courts. In a case 
of fifty laborers from Ogoni and Eket working in Fernando Pó, not a single person could come back to court, and the magistrate did "not accept SWORN STATEMENT" as there would have been no opportunity "for crossexamination." 112 Nevertheless, the six prosecutions for illegal recruitment to Fernando Pó in the district courts of Calabar, Aba, Owerri, Ikot Ekpene and Opobo courts in 1938 rose to over a hundred in 1941, and even more in $1943 .{ }^{113}$ This number, in one year, was more than double the total number of convicted cases of "child kidnapping" in Nigeria during the decade of the 1930s. ${ }^{114}$ Kingsley Mbadiwe, from the inner circle of Nnamdi Azikiwe's political party, the National Council of Nigeria and Cameroons, noted that, "[i]n the early forties one of the commonest crimes in the Eastern Region was illegal recruiting: the Region was infested with people who by specious promises, induced other people to seek employment in Fernando Po." Nevertheless, the various laws that "deal with slave dealers" proved to be "ineffective as a deterrent" as there were "always others ready to take their place because the traffic was very profitable," "the canoe men undoubtedly are seeing that they can get $£ 20$ for each labourers they can contract." ${ }^{115}$ Further complicating matters was the fact that the state was leaking heavily. S. Muyiwa, an undercover policeman with a heart of steel, shed light on the behavior of some of his colleagues, who he says had "decided that BRIBERY is the best means of living today at a laudable manner." The "inducement made the irresponsible recruiters to corrupt many a faithful servant of the Nigerian Government for many [had] been so degenerated that some of them serve as instruments to the Recruiters." ${ }^{116}$

Touts were an open category, constantly supplanted by various members of the commercial elite, by local fisherman, by traders from Dahomey, and even by former contract workers themselves. The tout's central nodal point was the colonial boom town of Oron, though they also required the appropriately inaccessible delta island of Atabong, just upstream from Oron, to serve as "the port of embarkation and return of canoes that do the smuggling" with Fernando Pó. ${ }^{117}$ Oron had a large transient population of "Ibo, Hausa and Yoruba communities," though the principal "stranger community" was "composed of Efiks from the Henshaw house." ${ }^{118}$ Already in 1938 the "Oron native authority council" was denouncing a local corporal's reign for having promoted "the daily increase of the number of Rogues and Criminals of all classes in Oron Clan, making the Oron Town their headquarters for evil practices. It is beyond doubt that he encourages crimes and sides with these Criminals." ${ }^{119}$ No techniques of colonial repression could expose or extinguish recruiters, because they did not operate outside a colonial space. They only stopped operating once the planters got their labor in other places or through different means. 


\section{Language and Violence on Fernando Pó}

The sudden boom of the "canoe traffic and its inhuman circumstances" triggered the "most serious phase of the Fernando Poo labour question," explained J.W. Kicks-Dadzie, the first journalist to enter the island after it fell to the fascist Falangista elements of the Spanish military in 1936. Kicks-Dadzie even interviewed the new Spanish Jefe de Policía, the police chief, Miguel Llompart Aulet, and implored him to "chase the wicked canoe traffickers out of the Island," to which Llompart flatly replied that he could "not possibly put a stop to it," as otherwise "they will not get labourers at all." If recruiters were con artists, then in Nigeria small sections of the colonially aligned voices of intellectuals, missionaries and officials were nonetheless complicit in their actions. Even Kicks-Dadzie praised the "highly scientific farming" of Fernando Pó's large settler plantations, as well as the Spanish colonial penal system and its "full" employment policy, as this allowed "no room for idlers, vagabonds and thieves." 120 The resident Methodist Reverend, Ewart Shepherd, also went out of his way to publicly praise the plantations, and their food rations and access to (minimal) health care. This he did while he watched as the "wholesale system of smuggling across in canoes" became "in vogue": "dozens of these canoes land their human cargoes in a little haven close to Santa Isabel. They come out of the creeks between Calabar and Victoria and the Nigerian Government is powerless to prevent them." ${ }^{21}$ The chief Methodist missionary in the region, the Igbo and Ibibio speaking Frederick Dodds, visited the island and was impressed by the façade of a fascist colony that in one stroke imprisoned "vagrants" en masse. During "the whole" of his month long trip in the spring of 1939, he "did not see a single ill-nourished" or "ill-clad" person. Dodds did, however, find the courage to "condemn" the means by which "much of the labour for the island is now being recruited. There is a constant stream of canoes filled with Nigerians, many of whom have been lured into taking the passage under promise of being taken elsewhere."122

Putting the middlemen in the crossfire, indulging projections of unwholesome and always suspect "middlemen" central to a Euro-Christian worldview, displaced and mystified the range of institutionalized imperial templates and legal grey areas that gave recruiting techniques their consistency and reach. Some British officials in the 1930s-the Governor in Lagos, Bourdillon, and the British Consul, Twigge Molecey, for exampleforegrounded not only a vocabulary that was designed to demonize mediators but also one that accused the victims themselves of backtracking or "changing their minds": "the 'slave dealers' have little or no difficulty in obtaining persons who are willing to go with them to Fernando Po, but 
the latter after 6 months try to abscond as they naturally miss their freedom and are unaccustomed to hard work." ${ }^{123}$ Some kidnapped workers also blamed themselves; one, named Ekpe Eyo, said "it was I who looked for money hence let this happen to me." ${ }^{124}$ But for most laborers on Fernando Pó, there was a world of difference between a peddler and an enforcer, between improvised solicitation and predatory appropriation, between voluntary but uncertain alliances and imposed filiation from without.

Actual coercion and violence resided in the ends, not the means, subsisting in the structure of imperial contract law. Deception, to set up a ruse, was eminently grounded in communication. But as Walter Benjamin says in his essay, the Critique of Violence, "verbal arrangements fundamentally exclude violence." ${ }^{\prime 25}$ To beguile is to steal through language, but on arrival one is at a loss only if one is prevented from leaving again. If workers could have left relatively unscathed, the way to panya would have simply been dismissed as a waste of time. The future braceros were at no point accosted or assaulted up until the point and no sooner than when they refused to sign a contract at the Curaduría. Though the drift of violence could certainly start on the canoe: the "recruiters did not always stop at promises of work" as "all too often a man who had to make a journey along the coast" would find "that the canoe was putting to sea: if he asked where it was going, he would be told that it was bound for Fernando Po, and that if he didn't want to go there he could jump overboard." On a canoe, there would be barely sufficient reason for an accusation of false imprisonment, a violation of habeas corpus, though definitely of reckless endangerment, the canoes, several a year, "from being overcrowded often upset, with the loss of everybody in them." ${ }^{126}$ Kicks-Dadzie even met and photographed "a batch of kidnapped labourers who were conveyed by canoe just a few weeks before" who told him: "Do all you can to stop the canoe traffic for majority of us had perished in the Sea." ${ }^{127}$

After describing the distressing daylong passage on the ocean-going canoe, Ekpe Eyo related how on firm ground in Santa Isabel's Curaduría he "argued that I will not stay, but they said that I would be sent to prison until after two years then we go." ${ }^{128}$ Anyone "lured to the Island [had] little chance of avoiding entering into a contract once they are there." ${ }^{129}$ The contract on the island was still mostly what Orde-Brown called of the "old type" or a "legal trap for the unwary native." 130 The order of contracts was not very elaborate, nor did it provide much room for manoeuvre, it was simply an obligation to "obey" it as law. ${ }^{131}$ The contracts were brought in almost wholesale via Cuba, through the template that the British gave the Spanish when they effectively arranged the hiring of Chinese coolies for them in the 1840s. In any case, what mattered most was a series of localized "Masters 
and Servants Acts, [without which] indenture would have been impossible." ${ }^{132}$ On Fernando Pó, it was not only that varying degrees of corporal punishment were permitted and used by both employers and the Spanish police, or that there were elaborate penal sanctions for breaking or refusing a contract - these were in full force until independence in 1968-but that "transgression" was a default. Arriving on the island without appropriate paperwork or connections landed one a bracero contract, with a forced signature on site. If "a labourer declined to accept the contract placed before him he can be treated under the existing Spanish laws, as a rogue and a vagabond," meaning jail-time with penal labor until forcibly contracted. ${ }^{133}$ The Spanish policy of having "anyone who arrives in this port, as soon as they disembark present themselves at the Curaduria," and of "forcing vagos without employers" to be put up "for contract in the Curaduría" had existed since 1910. This forced employment had obviously been "directed to the benefit of la agricultura in these lands, in light of the scarcity of brazos." ${ }^{134}$ These penal sanctions guaranteeing forced employment were the structural precondition of the recruitment spaces of Fernando Pós plantations as they extended around the Gulf of Guinea summoning and beckoning in their wake. ${ }^{135}$ No other medium or presupposition sustained and underpinned these panya recruitment operations and techniques. There was no labor mobility without recruiters or contracts; there was no circulation without meditation and inscription.

\section{Conclusion: Panya People Smuggling}

In the nineteenth century, touts, like the other informal brokers who had unsystematically and clandestinely been organizing most "indenture" labor migration (at least in what David Northrup calls the "early phase"136) started to be considered a disturbance, an interference, an impediment to the smooth-flowing and highly regulated "free" movement of people whose rational arrival at their destination as proper "capitalist" workers was imaged to be the retroactive result of a transparent and informed displacement, requiring both the state-surveyed infrastructures of registration and explanation and the ideological ideal of an self-sovereign subject. The decision to move and take up a contract was to be made without undue influences or duress coming from stranger-brokers or even from over-bearing family members. In Nigeria, with the Labour Ordinance No. 1 of 1929, as in other colonial territories, bureaucratic means were brought in to license recruitment and emigration to "ensure that illiterate or inexperienced men were safeguarded against rapacious employers, traders and others." 137 Their impulse was to "de-victimize" indentured labor recruitment by removing 
randomness and innocence, though this by itself did not lead to less exploitative working conditions. Attempts by the British through the 1942 labor treaty to create a paper trail for the declarations of consent were a way to make labor movements and relations conform to imagined laws of exchange and self-interest. It was a bureaucratic mechanism intended to disenchant the labor market through a congruent arrangement of expectations and realities. This was a way to legitimize employers' exploitation, allowing them to continue their plantation regime under practically unaltered conditions of work, and sustain the perpetuation of colonial plantations. The colonial plantation island required a certain set of contractual templates and vagrancy ordinances to sustain itself, its order and productivity. The formal legal structure of the colonial plantation economy was the same one that allowed touts to flourish in the first place. Contracts were bondage contracts, with their own bounded consistency, which nevertheless generated potential outgrowths and prefigured disparate modalities of recruitment. The contracts of panya allowed the randomness and violence of panyarring to be, as dialecticians would say, "sublated," or simultaneously eliminated and preserved, carried on almost purely through the broken prism of language on the West African coast.

A look at the specific periods and places where touts ruled recruitment through economies of deception raises some interesting questions for global labor history, and particularly for the "mesmerizing contrast between 'free' and 'unfree' labour." That the "recruitment of labour proceeded in more complex ways than our stultifying orthodoxies suggest" is clear by now. ${ }^{138}$ Touts were one of the indispensable and varied rhythms of the "middle" of the spectrum, but they were not simply a "blur"- "semi" or "half-way" types. Their ossification into a type, or their blurring into a spectrum, forecloses the reasons for their range of maneuvers and potentials. Touts intensified and unraveled either end, throwing the conceptual pillars of clarity-free and unfree, coercion and consent-into disarray. Their frequency was volatile and ambivalent. While relinquishing the bravura of binary ultimatums, the historiography has seemed to stagnate on the same realization that disturbed nineteenth century abolitionists who also saw labor along a foggy order of slippages and resemblances, along "a very broad continuum rather than as a binary opposition," without taking the actual operations and experiences of such blurs into account. ${ }^{139}$ Abduction could be experienced as a beam of shock and removal to the unknown, but also the displaced result of encounters plagued by an awry two-facedness of snares and lures. This range was considered by many British abolitionist officials in an imperial world to be a "species of slavery or kidnapping." ${ }^{140}$ Those naming the practice sprinkled their terms with important prefixes 
generating a parallel whose gap or degree of similitude was uncertain. This uncertainty, along with the intensely localized nature of the practice, is one of the reasons why such recruiting techniques generated so many slang terms to designate itself: shanghaiing, blackbirding, to be barbadosed, trepanned, phuslaoed or spirited by crimps, spirits, land-sharks, snakes and the like, an "erratic" labor market whose most widespread and consistent feature was "knavery," being "cajoled by plausible touts."141

Panya shares specific junctions with a global labor history, where the same pattern of recruitment is found, lasting also from one to several decades, and containing the same constant spatial shift: between London and Barbados or Virginia in the 1640s or during the Napoleonic wars in the 1790s; across the early nineteenth century American seaboard, first east then west; in the 1840s around many places, including the Windward coast, the port towns in the Bay of Bengal and Xiamen and Macau, late nineteenth century Oceania, between Vanuatu, Solomon Islands or New Guinea and Queensland, Fiji and Peru. The medium-term persistence of touts has been amply demonstrated for early twentieth century Southern Africa, shifting at the junctions between Mozambique, Southern Rhodesia, and the Transvaal. There the creative process of "fraud and misrepresentation" by unlicensed "'rapacious labour touts and criminal gangs," who made "promises which they did not intend to keep," were described by local administrators and academics as having "degenerated into "nothing more or less than a sort of slave trade.'"142

The economy of deception in the recruitment of indentured labor is usually attached to "force" by its analysts: blackbirding was "dishonest and violent," spiriting was "fraudulent and coercive," and meant being "violently taken away or cheatingly duckoyed," "either through deception or direct violence," "victims were kidnapped, tricked by offers of good jobs," "all forms of persuasion and coercion were employed" by recruiters who painted "a rosy picture" and the "poor workers often fell prey to these ploys," finding themselves becoming "victims of empty promises," all in all, a kind of "enticement/kidnapping." ${ }^{43}$ The different segments of a recruitment trajectory are often collapsed. The same range of conflationary vocabulary is used in definitions of "trafficking in persons" in the twenty-first century. ${ }^{144}$ This double bind of language and violence is connoted in panya, but logically they occur apart, in place and in time. This ambivalence provides credence to more recent critiques of the widely deployed notion of "human trafficking" and the (mis)representation of its victims. While sociologists often speak in terms of choice and risk, assuming an individualistic configuration of personhood, they highlight the importance of accepting the migrants' own nuanced gradients of dysphoria and transport needs, their 
acceptance of the opaque and unpredictable logistics of illicit brokers. It is touts who have the means and know-how to "assist" the unauthorized emigration to destinations with a labor market, where migrants may or may not experience or expect severe coercion at the hands of disciplinarian employers or the punitive state-both of which were brought to bear on Fernando Pó against anyone who refused work, or wanted to change employers, or sought to return home before the expiration of the contract. ${ }^{145}$

The pattern of the technique is clear: first the trick, then the force; first the farce, then the tragedy. The first segment is referred to with endless synonyms for deception, that in comparison to "force," borders on the obscenely light-hearted, almost playful, infantilizing and incredulous-to trick. However, the "trick," as a vector of instrumental language for the commodification of the desire, is an axiomatic, consistent and creative capitalist praxis, present also in the grease that allowed imperial labor recruitment. Touts were one of the symptoms of the expansion of the internal limits of capitalism and its arenas of operation, everyday commercial dealings with opaque others, containing hazards and seductions. Out of the imperial establishment of port towns and transport junctions, the global depression of crashing palm oil prices, colonial tax hikes and the localized monetization of social life, came the crushing promise of possibilitiesand the need to be on the move in order to draw on these.

Humboldt University-Berlin

\section{Notes}

The doctoral research leading to these results has received funding from the European Union's Seventh Framework Programme (FP7/2007-2013) under ERC Starting Grant no. 240898. I am grateful to many people for various comments, and especially to Zachary Kagan Guthrie, Adam McKeown, Andreas Eckert, Ugo Nwokeji, Paul Lovejoy, David Pratten, Chika Onyenezi, Jelmer Vos and Cassandra Mark-Thiesen. I would also like to thank Benita Sampedro and Dmitri van den Bersselaar for making possible the presentations out of which this paper first grew, at Hofstra University in New York and at the African Studies Association conference in Baltimore in November 2013. Abbreviations for archival citations: DGMC = Dirección General de Marruecos y Colonias (Colonial Office, Madrid); GG = Gobernador General de los Territorios Españoles del Golfo de Guinea (Governor, Santa Isabel); Curaduria = Curador Colonial (Labor Officer, Santa Isabel); British VC = British Vice-Consul (Santa Isabel); DO = District Officer (of Nigerian Districts or Divisions). 
1. G. Ugo Nwokeji, The Slave Trade and Culture in the Bight of Biafra (New York: Cambridge University Press, 2010), 127, 131; Nwojeki says that "to panya" is the Igbo verb form of panyarring and links it to the "child-stealing" practice of the Aro (personal communication, December 2014). Panyarring has its own pidgin etymology, most likely from the Portuguese word apanhar "to grab" or to "seize," but the term also had a broad valence, as it referred to possession and theft in different contexts, such as spirit possession and "man-stealing" or anonymous kidnapping. Hans Christian Monrad, Two Views from Christiansborg Castle: A Description of the Guinea Coast and Its Inhabitants (Legon: Sub-Saharan Pub, 2009), 57, 220. Panya was by the twentieth century totally delinked from the most common definition of panyarring, or the slaving practice, present up until the late nineteenth century in various parts of West Africa, of debt-collection or communal retribution that resulted from the break-down of pawnship and the repayment of credit. Olatunji Ojo, “'Èmú' (Àmúyá): The Yoruba Institution of Panyarring or Seizure for Debt," African Economic History 35 (2007): 31-58; Paul E. Lovejoy, "Pawnship, Debt, and "Freedom" in Atlantic Africa During the Era of the Slave Trade: A Reassessment," The Journal of African History 55, 1 (2014): 55-78, 59.

2. John Ranby, Observations on the Evidence Given Before the Committees of the Privy Council and House of Commons in Support of the Bill for Abolishing the Slave Trade (London: John Stockdale, 1791), 83.

3. "Smuggling - Nigeria's curse," Drum, Lagos, January 1961; Donald C. Simmons, "Analysis of the Reflection of Culture in Efik Folktales" (PhD diss., Yale University, 1957), 26; Datguru, "Where Is PANYA In Nigeria?" Fairaland Forum, 1 July 2014, http://www.nairaland.com/1794650/where-panya-nigeria; E. Nolue Emenanjo, "Slangs and Colloquialisms in Modern Igbo: A Preliminary SocioLinguistic Study," Ikenga: Journal of African Studies 4, 2 (1980): 49-65, 52.

4. Governor of Nigeria, Lagos to British Consul-General, Duala, 16 January 1945, National Archives of Nigeria, Enugu [hereafter NAE], CALPROF 17/1/277.

5. Felix K. Ekechi, Pioneer, Patriot, and Nigerian Nationalist: A Biography of the Reverend M.D. Opara, 1915-1965 (Durham: Carolina Academic Press, 2010), 60, 261; Fieldwork Notes, July 2012.

6. British VC to the Resident, Calabar Province, 30 November 1938, NAE, CALPROF 5/1/194; Supt. of Police, Calabar to Comm'r of Police, Lagos, 30 December 1938, NAE, CALPROF 5/1/194; "Fernando Po Labour Conditions," The Nigerian Daily Times, Lagos, 13 July 1939.

7. "Nigeria over the Water," West Africa, London, 1 January 1958.

8. David Pratten, The Man-Leopard Murders: History and Society in Colonial Nigeria (Edinburgh: Edinburgh University Press, 2007), 165.

9. Henderson M. Tapela, "Nigerian Labour for Fernando Po," The Calabar Historical Journal 3, 1 (1985): 36-56, 51; Akinjide Osuntokun, Equatorial Guinea Nigerian Relations: The Diplomacy of Labour (Lagos: Oxford University Press, 1978), 40.

10. O. Archibong to the Resident, Calabar Province, 23 January 1939, NAE, CALPROF 5/1/194. 
11. DO, Uyo to the Resident, Calabar Province, 11 January 1939, NAE, CALPROF 5/1/194.

12. Simpson, Special Operations Executive, Ministry of Economic Warfare to Comm'r of Labour, Lagos, 20 December 1942, "Final Report on Fernando Po and Spanish Guinea, 1942-1943," National Archives of the UK, London [hereafter TNA], HS 3/77.

13. British VC to Comm'r of Labour, Lagos, 2 April 1952, TNA, 371/96714.

14. David Northrup, Indentured Labor in the Age of Imperialism, 1834-1922 (Cambridge: Cambridge University Press, 1995), 6.

15. G. St. John Orde-Browne, Labour Conditions in West Africa (London: H. M. Stationary Office, 1941), 47, 71.

16. Paul E. Baak, "About Enslaved Ex-Slaves, Uncaptured Contract Coolies and Unfreed Freedmen: Some Notes about 'Free' and 'Unfree' Labour in the Context of Plantation Development in Southwest India, Early Sixteenth Century-Mid 1990s," Modern Asian Studies 33, 1 (1999): 121-57, 124; Northrup, Indentured Labor, 7; see also David Eltis, The Rise of African Slavery in the Americas (Cambridge: Cambridge University Press, 2000), 200; Verene A. Shepherd, “'The Other Middle Passage?' Nineteenth-Century Bonded Labour Migration and the Legacy of the Slavery Debate in the British-Colonized Caribbean," in Working Slavery, Pricing Freedom: Perspectives from the Caribbean, Africa and the African Diaspora, ed. Verene A. Shepherd (New York: Palgrave, 2002), 343-377.

17. Marina Carter, "Strategies of Labour Mobilisation in Colonial India: The Recruitment of Indentured Workers for Mauritius," Journal of Peasant Studies 19, 3/4 (1992): 229-45, 238.

18. Hugh Tinker, A New System of Slavery: The Export of Indian Labour Overseas, 1830-1920 (London: Oxford University Press, 1974), 116, 124; see also Richard B. Allen, "Re-Conceptualizing the 'New System of Slavery'," Man In India 92, 2 (2012): 225-45.

19. David Aworawo, "Decisive Thaw: The Changing Pattern of Relations between Nigeria and Equatorial Guinea, 1980-2005," Journal of International and Global Studies 1, 2 (2010): 89-109, 92.

20. Niklas Frykman, "Impressment, Kidnapping, and Panyarring," in The Princeton Companion to Atlantic History (Princeton: Princeton University Press, 2015), ed. Joseph Miller, 240-42, 242; Peter Linebaugh and Marcus Rediker, The ManyHeaded Hydra: Sailors, Slaves, Commoners, and the Hidden History of the Revolutionary Atlantic (New York: Verso, 2000), 133.

21. Monica Schuler, "The Recruitment of African Indentured Labourers for European Colonies in the Nineteenth Century," in Colonialism and Migration: Indentured Labour Before and After Slavery, ed. Peter Emmer (New York: Springer, 1986), 125-60, 127.

22. Carter, "Strategies of Labour Mobilisation," 243.

23. John Wareing, "'Violently Taken Away or Cheatingly Duckoyed': The Illicit Recruitment in London of Indentured Servants for the American Colonies, 16451718," The London Journal 26, 2 (2001): 1-22, 4, 6. 
24. Richard B. Allen, "European Slave Trading, Abolitionism, and 'New Systems Of Slavery' in the Indian Ocean," PORTAL: Journal of Multidisciplinary International Studies 9, 1 (2012), https://epress.lib.uts.edu.au/journals/index.php/portal/ article/view/2624, 2.

25. Robert Smith, “The Lagos Consulate, 1851-1861: An Outline,” The Journal of African History 15, 3 (1974): 393-416, 415.

26. William G. Clarence-Smith, "Emigration from Western Africa, 1807-1940," Itinerario 14, 1 (1990): 45-60; David Northrup, "Freedom and Indentured Labor in the French Caribbean, 1848-1900," in Coerced and Free Migration: Global Perspectives, ed. David Eltis (Stanford: Stanford University Press, 2002), 205-228; Rosanne Marion Adderley, "New Negroes from Africa": Slave Trade Abolition and Free African Settlement in the Nineteenth-century Caribbean (Bloomington: Indiana University Press, 2006) 74-75. For more on the ample French efforts to supply Martinique, Guadeloupe, Reunion and Mayotte with engage á temps labor from Senegal, Gabon, Dahomey and Mozambique, see François Renault, Libération D'esclaves et Nouvelle Servitude: Les Rachats de Captifs Africains Pour Le Compte Des Colonies Françaises Après L'abolition de L'esclavage (Abidjan: Les Nouvelles Éditions Africaines, 1976); Elisee Soumonni, "The Compatibility of the Slave and Palm Oil Trades in Dahomey, 1818-1858," in From Slave Trade to "Legitimate" Commerce, ed. Robin Law (Cambridge: Cambridge University Press, 1995), 78-92, 86; Jelmer Vos, “'Without the Slave Trade, No Recruitment': From Slave Trading to 'Migrant Recruitment' in the Lower Congo, 1830-90," in Trafficking in Slavery's Wake: Law and the Experience of Women and Children in Africa, eds. Benjamin N. Lawrance and Richard L. Roberts (Athens: Ohio University Press, 2012), 45-64; Alessandro Stanziani, Bondage: Labor and Rights in Eurasia from the Sixteenth to the Early Twentieth Centuries (New York: Berghahn Books, 2014), 175-196.

27. Suzanne Miers and Richard Roberts, "The End of Slavery in Africa," in The End of Slavery in Africa, eds. Suzanne Miers and Richard Roberts (Madison: University of Wisconsin Press, 1988), 3-70, 20, 21, 54; William G. Clarence-Smith, "Labour Conditions in the Plantations of Sao Tomé and Prıncipe, 1875-1914," Slavery and Abolition 14, 1 (1993): 149-167, 149.

28. Suzanne Miers, "Slavery and the Slave Trade as International Issues 18901939," Slavery and Abolition 19, 2 (1998): 16-37, 29. See also Ibrahim Sundiata, From Slaving to Neoslavery: The Bight of Biafra and Fernando Po in the Era of Abolition, 1827-1930 (Wisconsin: University of Wisconsin Press, 1996), 123, 143; Ibrahim Sundiata, Brothers and Strangers: Black Zion, Black Slavery, 1914-1940 (Durham: Duke University Press, 2004), 81, 88-98, 249-250.

29. Paul E. Lovejoy, Transformations in Slavery: A History of Slavery in Africa (Cambridge: Cambridge University Press, 2011), 288, 299; Adiele E. Afigbo, The Abolition of the Slave Trade in Southeastern Nigeria, 1885-1950 (Rochester: University Rochester Press, 2006), 100; Patrick Manning, Slavery and African Life: Occidental, Oriental, and African Slave Trades (Cambridge: Cambridge University Press, 1990), 161; see also Paul E. Lovejoy and Jan Hogendorn, Slow Death for Slavery: The Course of Abolition in Northern Nigeria, 1897-1936 (Cambridge: Cambridge University 
Press, 1993); Suzanne Miers, "Slavery to Freedom in Sub-Saharan Africa: Expectations and Reality," in After Slavery: Emancipation and Its Discontents, ed. Howard Temperley (London: Frank Cass, 2000), 237-64. For the foundational thesis of the resilience of old elites, see Ralph A. Austen, "The Abolition of the Overseas Slave Trade: A Distorted Theme in West African History," Journal of the Historical Society of Nigeria 5, 2 (1970): 257-274.

30. Most Igbo recruiters operated in and out of Bende, but they lived elsewhere. For example, Michael Ikeocha was from Oloko, in Bende division, a town whose women instigated the Ogu Umunwanyi or Women's War of 1929; it was likely for that reason that he found himself "now living a Calabar" in the compound of Chief Udo Edem. Ikeocha made "his journeys" from Creek Town. British VC, 28 February 1942, "Labour Conditions in Spanish Guinea, Appendix C," TNA, FO 371/26908. Warren T. Morrill, "Two Urban Cultures of Calabar, Nigeria” (PhD diss., University of Chicago, 1961), 269, notes from his field site, 1950s Calabar, that "all Igbo migrants in Calabar" assured him that the "shrewdest and most successful Ibo traders are those from Abiriba." A reputation carried on into more recent times too, as a blogpost on Nairaland says: "The Abiriba man loves and follows the whiff of money to wherever it takes him, and no matter the risk involved," having "responded to changing economic opportunities" in the colonial period by "developing a strong trade in smuggled gin from Fernando Pó." Ebere Ahanihu, "Abiriba And Ohafia: Two Of A Kind,” 30 April 2011, http://www.nairaland.com/657067/ abiriba-ohafia-two-kind.

31. Such headmen were integral to Kru (1830s-1890s) labor migrations. Elizabeth Tonkin, "Creating Kroomen: Ethnic Diversity, Economic Specialism and Changing Demand," in Africa and the Sea: Proceedings of a Colloquium at the University of Aberdeen, ed. Jeffrey C. Stone (Aberdeen: University of Abderdeen, 1985), 27-47, 35; Diane Frost, Work and Community among West African Migrant Workers since the Nineteenth Century (Liverpool: Liverpool University Press, 1999), 40. See also Cassandra Mark-Thiesen, “The 'Bargain' of Collaboration: African Intermediaries, Indirect Recruitment, and Indigenous Institutions in the Ghanaian Gold Mining Industry, 1900-1906," International Review of Social History 57, 20 (2012): 17-38. In the "post-indenture" Bay of Bengal and South East Asia, such recruitment through "boss-boys" was known as the kangani ("overseer" in Tamil) and chu tsai thau ("head of piglets"). Palanisamy Ramasamy, "Labour Control and Labour Resistance in the Plantations of Colonial Malaya," Journal of Peasant Studies 19, 3/4 (1992): 87-105.

32. Adam Mckeown, “Global Migration, 1846-1940," Journal of World History 15, 2 (2004): 155-89, 167; Philip D. Curtin, Why People Move: Migration in African History (Waco: Markham Press Fund, 1995). For a contemporary critique of "social networks" see Fred Krissman, "Sin Coyote Ni Patrón: Why the 'Migrant Network' Fails to Explain International Migration," International Migration Review 39, 1 (2005): 4-44. For a critique of the "separation between contractor and sardari recruitment," where the latter, the sardar was "perceived to be an 'insider' recruiting within a proximate community and thus less likely to use force and deception in recruitment," see Samita Sen, "Commercial Recruiting and Informal Intermediation: 
Debate Over the Sardari System in Assam Tea Plantations, 1860-1900," Modern Asian Studies 44, 1 (2010): 3-28, 5; Prabhu P. Mohapatra, "Eurocentrism, Forced Labour, and Global Migration: A Critical Assessment," International Review of Social History 52, 1 (2007): 110-15, 113.

33. Heinrich A. Wieschhoff, Colonial Policies in Africa (Philadelphia: University of Pennsylvania Press, 1944), 32.

34. Henderson M. Tapela, "The Cross River Basin: Colonial Labour Policies and Practices," in A History of the Cross River Region of Nigeria, ed. Monday B. Abasiattai (Calabar: University of Calabar Press, 1990), 198-214, 210.

35. William G. Clarence-Smith, "Cocoa Plantations and Coerced Labor in the Gulf of Guinea, 1870-1914," in Breaking the Chains: Slavery, Bondage and Emancipation in Africa and Asia, ed. Martin A. Klein (Madison: University of Wisconsin Press, 1993), 150-70, 160.

36. John D. Fage, "Upper and Lower Guinea," in The Cambridge History of Africa: Volume 3 from c. 1050 to c. 1600, eds. Roland Oliver and John D. Fage (Cambridge: Cambridge University Press, 1977), 463-518; Joseph C. Miller, Way of Death: Merchant Capitalism and the Angolan Slave Trade, 1740-1830 (Madison: University of Wisconsin Press, 1988), 115-6; Arlindo Manuel Caldeira, "Learning the Ropes in the Tropics: Slavery and the Plantation System on the Island of São Tomé," African Economic History 39 (2011): 35-71.

37. British VC to Comm'r of Labour, Lagos, 26 June 1950, TNA, CO 554/169/1.

38. Tapela, "The Cross River Basin," 210; Tapela, "Nigerian Labour for Fernando Po," 45.

39. Nkparom C. Ejituwu, "Anglo-Spanish Employment Agency: Its Role in the Mobilization of Nigerian Labour for the Island of Fernando Po," in The NigeriaEquatorial Guinea Transborder Cooperation, eds. Bawuro M. Barkindo, A. I. Asiwaju, and Ricardo Elo Mabale (Lagos: Terminal Products, 1995), 42-57. There were 103,881 new recruits brought in through the treaty in the first twenty years of its operation (1943-1962): Comisión para el Desarrollo Económico de Fernando Poo y Rio Muni, "Plan de desarrollo económico de la Guinea Ecuatorial: 1964-1967" (Madrid: Presidencia del Gobierno, 1963), Anexo 10. No one has quantified 1962 to 1968 , or beyond to 1975 . The revised 1963 Treaty with the Nigerian state doubled the length of the minimum contract to three years (and four and half in total). A reliable figure for 1964 is that under the treaty some "40,000 Nigerians" were under contract in Fernando Pó, in addition to "10,000" in Rio Muni. United States Department of Labor, Labor Digests on Countries in Africa (Washington: Bureau of Labor Statistics, 1966), xxxiii.

40. Martin Lynn, "Review: 'Black Capitalism'," The Journal of African History 38, 3 (1997): 503-5; Martin Lynn, "Commerce, Christianity and the Origins of the 'Creoles' of Fernando Po", The Journal of African History 25, 3 (1984): 257-78; William G. Clarence-Smith, "African and European Cocoa Producers on Fernando Poo, 1880s to 1910s," The Journal of African History 35, 2 (1994): 179-99.

41. Sundiata, From Slaving to Neoslavery, 23, 130; William G. Clarence-Smith, Cocoa and Chocolate, 1765-1914 (London: Routledge, 2000), 80; Bassa were a Kru 
coastal group whom a resident German scientist on Fernando Pó in the 1880s paradoxically decided to describe as both "very lazy, and unsettled and restless, and who assimilate quickly into the ranks of the Poto," or Fernandinos. Oscar Baumann, Eine afrikanische Tropeninsel Fernando Poo und die Bube (Wien: Hölzel, 1888), 140.

42. Anne Phillips, The Enigma of Colonialism: British Policy in West Africa (London: J. Currey, 1989), 34; Kristin Mann, Slavery and the Birth of an African City: Lagos, 1760-1900 (Bloomington: Indiana University Press, 2007), 234. See also Dolores García Cantús, "Fernando Poo: una aventura colonial española en el África Occidental (1778-1900)" (PhD diss., Universitat de València, 2004), 567.

43. Gerald M. McSheffrey, "Slavery, Indentured Servitude, Legitimate Trade and the Impact of Abolition in the Gold Coast, 1874-1901: A Reappraisal," The Journal of African History 24, 3 (1983): 349-368, 360; Emmanuel Akyeampong, Between the Sea and the Lagoon: An Eco-Social History of the Anlo of Southeastern Ghana, c. 1850 to Recent Times (Oxford: James Currey Publishers, 2001), 70.

44. Sundiata, From Slavery to Neoslavery, 130. Most "laborers leaving Liberia were" low caste Vai and Mandinka, and Kpelle. Ibrahim Sundiata, "The Rise and Decline of Kru Power: Fernando Po in the 19th Century," Liberian Studies Journal 6, 1 (1975): 25-43, 35.

45. Jane Martin, "Krumen 'Down the Coast': Liberian Migrants on the West African Coast in the 19th and early 20th centuries," The International Journal of African Historical Studies 18, 3 (1985): 401-423, 408; Monica Schuler, "Kru Emigration to British and French Guiana, 1841-185," in Africans in Bondage: Studies in Slavery and the Slave Trade, eds. Philip D. Curtin and Paul E. Lovejoy (Madison: University of Wisconsin Press, 1986), 155-201.

46. Richard F. Burton, Wanderings in West Africa from Liverpool to Fernando Po, Vol. II (London: Bradbury and Evans, 1862), 2.

47. British VC, 28 February 1942, "Labour Conditions in Spanish Guinea," TNA, FO 371/26908; Osuntokun, Equatorial Guinea Nigerian Relations, 25.

48. Henry Carr, Education Office, Lagos, 20 February 1900, "Report on the Condition and Treatment of Labourers just returned from Fernando Po," Archivo General de la Administración, Alcalá de Henares, Spain, IDD 15, Fondo África [hereafter AGA], Caja [hereafter C] 81/07789, Expediente [hereafter E] 2; J.M. Rafel, Santa Isabel to GG, 3 December 1932, AGA, C-81/08128, E-12.

49. Only colonial settlers and those with emancipado status, an exclusive license granted to only a very small number of Fernandinos, could actually formally contract braceros. British Consul General, Monrovia to Foreign Office, London, 15 October 1913 [and] 30 June 1913, TNA, FO 367/353; Sundiata, From Slaving to Neoslavery, 136, citing Lt. Strong, 5 August 1912, "Report on the Exportation of Native Labour from Liberia to Fernando Po," TNA, FO 367/286.

50. Joseph Asaba, Victoria, to Provincial Comm'r Calabar, 22 October, 1911, TNA, FO 367/254; German West African Trading Company, Rio del Rey to Provincial Comm'r, Calabar, 17 October 1911, TNA, FO 367/254.

51. High Commissioner's Office, Calabar to GG, 12 April 1905, AGA, C-81/ 07789, E-2. 
52. Olatunji Ojo, “The Southern Nigeria Native House Rule Ordinance (1901)," African Economic History 40 (2012): 127-36, 133.

53. Solicitor for Chief Marin Braid, Calabar to GG, 18 October 1905, AGA, C-81/07789, E-2; GG to DGMC, 31 December 1912, AGA C-81/06945, E-20.

54. GG to DGMC, 28 December 1935, AGA, C-81/06867, E-5; British Consul, Yaounde, 4 May 1961, “Despatch No.46,” TNA, CO 554/2502.

55. Tapela, "The Cross River Basin," 210, 212; Ejituwu, "Anglo-Spanish Employment Agency," 50.

56. Aba Commission of Inquiry, Notes of Evidence Taken by the Commission of Inquiry Appointed to Inquire into the Disturbance in the Calabar and Owerri Provinces, December, 1929 (Lagos: Government Printer, 1930), para. 18675, 18570; Ebenezer Obadare, "Nigeria-Equatorial Guinea Relations since 1927: A Critique of the Historiography," in The Foundations of Nigeria: Essays in Honor of Toyin Falola, ed. Toyin Falola (Trenton: Africa World Press, 2003), 575-589, 577; Andrew C. Okolie, "The Transformation of Eastern Nigeria: From Self Sufficiency to Social Crisis," in Ibid., 449-472, 461, 463.

57. A. F. B. Bridges, June 1938, "Report of Oil Palm Survey, Ibo, Ibibio and Cross River Areas," Rhodes House Library, Oxford [hereafter RHL], Mss. Afr. S. 697 (1), para. 3; see also Chima Korieh, The Land Has Changed: History, Society and Gender in Colonial Eastern Nigeria (Calgary: University of Calgary Press, 2010), 260.

58. British Labour Officer, Santa Isabel to British Consul General, Douala, 31 August 1945, NAE, CALPROF 17/1/278; British VC, 4 July 1956, "Quarterly Report”, TNA, CO 554/1346; Chief Secretary Office, Lagos to GG, 7 July 1930, AGA, C- 81/08146 E-1.

59. Labour Officer, Calabar, to Comm'r of Labour, Lagos, 6 December 1943, NAE, CALPROF 5/1/193.

60. Nigerian Secretariat, Lagos, 1953, "Memorandum on the labour connection between Nigeria and the Spanish territories in the Gulf of Guinea", RHL, 600.18 s. 21/XI (10).

61. DO, Itu to the Resident, Calabar Province, 11 January 1939, NAE, CALPROF 5/1/194; Comm'r of Police, Calabar to the Resident, Calabar Province, 1 August 1935, NAE, CALPROF 5/1/192.

62. Rafael Cavestany Anduaga, El Consejero Técnico a la XIX Conferencia Internacional de Trabajo, 22 May 1935, AGA, C-81/12422.

63. A. Babiloni Navarro, December 1936, "Los Territorios Españoles del Golfo de Guinea vistos por un Colono al terminar el año 1936," AGA, C-81/12427.

64. Guillermo Cabanellas, La selva siempre triunfa: novela del África española (Buenos Aires: Editorial Ayacucho, 1944), 35.

65. Ejituwu, "Anglo-Spanish Employment Agency," 47.

66. DO, Opobo to rhe Resident, Calabar Province, 10 June 1947, NAE CALPROF 3/1/1447; Resettlement Office, Uyo to The Resident, Calabar Province, 1 July 1947, NAE CALPROF 3/1/1447

67. "The Fernando Po Slave Traffic," The Nigerian Eastern Mail, Calabar, 25 February 1939. 
68. Pratten, The Man-Leopard Murders, 166; Osuntokun, Equatorial Guinea Nigerian Relations, 27; Tapela, "Nigerian Labour for Fernando Po," 48.

69. Timothy Farley Smith and Nigeria, Report on employment of Nigerian labour in Fernando Poo (Lagos: Government Printer, 1931), para. 6.

70. Dandeson Green, "Recruitment of Labour To Fernando Po is Done Under Treaty With Spanish Govt," Eastern Nigeria Guardian, Port Harcourt, 17 April 1947; Green was in 1952 appointed "Labour Delegate to the Agency" of licensed recruitment to "provide propaganda which will encourage recruitment and to combat any adverse criticism by the popular press in the Eastern Region, Nigeria." British VC, 31 September 1952, TNA, FO 371/96714.

71. Olatunji Sapara, [n.d. 1934] contained in Comm'r of Police, Buea to the Resident, Calabar Province, 31 January 1934, NAE, CALPROF 5/1/192.

72. Special Correspondent [Kicks-Dadzie], "Fernando Po Labour Conditions." The Nigerian Daily Times, Lagos, 13 July 1939.

73. F.W. Dodds, July 1939, "Notes on Visit to West African District, February to June 1939," SOAS Archives, London, Archives of the Methodist Missionary Society, MMS/Special Series/Notes and Transcripts/FBN 1 (fiche 15-17). Spanish Guinea accounted for 1\% of total exports from Africa in 1960, even though it had about $0.1 \%$ of Africa's land and population. In 1960 GDP per capita was $\$ 135$, in contrast to Nigeria where it stood at $\$ 12$. René Pélissier, Los territorios españoles de Africa (Madrid: Consejo Superior de Investigaciones Científicas, 1964), 44, 62.

74. "Writer vehemently condemns idea of Labour Recruiting to Fascist Territory," Eastern Nigeria Guardian, Port Harcourt, 1 March 1945.

75. British VC to Comm'r of Labour, Lagos, 14 April 1953, TNA, FO 371/102612.

76. Simpson, to Comm'r of Labour, Lagos, 20 December 1942, TNA, HS 3/77; British VC, 17 June 1943, "Nigerian Labour in Fernando Poo," TNA, CO 554/127/15.

77. Emilio Carles, Misioneros, negreros y esclavos: Notas de un viaje a Fernando Poo (Valencia: Cuadernos de Cultura, 1932), 34; Sen, "Commercial Recruiting and Informal Intermediation," 15, citing Deputy Commissioner of Ranchi, 13 April 1899.

78. J.W. Kicks-Dadzie to the Resident, Calabar Province, September 1939, "Confidential Report: Labour in Fernando Poo," NAE, CALPROF 5/1/195; see also Tapela, "Nigerian Labour for Fernando Po," 48; citing his interview with Federal Ministry of Labour, Calabar, 31 August 1978.

79. British VC to Comm'r of Labour, Lagos, 11 June 1946, "Illegal Recruitment in Nigeria by 'ganchos' appointed by Spanish Employers," NAE, CALPROF 17/1/278.

80. Tapela, "Nigerian Labour for Fernando Po," 48.

81. Ekpe Eyo, Santa Isabel to Eyo Ubon, Afaha Atai, Uyo Division, Calabar Province, 2 September 1938, NAE CALPROF 5/1/194 [original in Ibibio in NAE, CALPROF 5/1/195].

82. Letter to Etim, [n.d., received by the Resident at Calabar from the Hope Weddell Institute in July 1934], NAE CALPROF 5/1/192.

83. Orde-Brown, Labour Conditions in West Africa, 74; Nigeria, "Report on the Administration of the British Cameroons for the year 1938," TNA, CO 583/239/5. 
84. Your Prodigal Sons to the Resident, Calabar Province, 24 March 1936, NAE, CALPROF 5/1/194.

85. Observer, "Matters of Moment," The Nigerian Daily Times, Lagos, 15 July 1939; "Spanish Slavery," The Nigerian Eastern Mail, Calabar, 11 March 1939.

86. Saheed Aderinto and Paul Osifodunrin, “500 Children Missing in Lagos': Child Kidnapping and Public Anxiety in Colonial Nigeria," in Children and Childhood in Colonial Nigerian Histories, ed. Saheed Aderinto (New York: Palgrave Macmillan, 2015), 97-121, 102; Secretary's Office, Eastern Provinces, Enugu, to Comm'r of Labour, Lagos, 14 July 1949, NAE, CALPROF 7/1/458; "I was sold as a slave at the age of two," Daily Times, Lagos, 11 June 1958.

87. British VC, 17 June 1943, "Nigerian Labour in Fernando Poo," TNA, CO 554/127/15; O. Archibong to the Resident, Calabar Province, 23 January 1939, NAE, CALPROF 5/1/194.

88. Misty L. Bastian, "Fires, Tricksters and Poisoned Medicines: Popular Cultures of Rumor in Onitsha, Nigeria and Its Markets," Etnofoor 11, 2 (1998): 11132, 123; Julien Bonhomme, "The Dangers of Anonymity: Witchcraft, Rumor, and Modernity in Africa," HAU: Journal of Ethnographic Theory 2, 2 (2012): 205-33, 226.

89. DO, Eket to the Resident, Calabar Province, 16 January 1939, NAE, CALPROF 5/1/194.

90. British VC to Consul General, Monrovia, 12 July 1944, TNA, FO 371/39661; British VC to British Consul General, Monrovia, 18 February 1939, TNA, CO 554/119/5.

91. DO, Uyo to the Resident, Calabar Province, 11 January 1939, NAE, CALPROF 5/1/194; DO, Aba to the Resident, Calabar Province, 10 May 1939, NAE, CALPROF 5/1/195; DO, Opobo to Native Court Clerks, Ibibio and Annang, January 1939, NAE, CALPROF 5/1/194.

92. Nigeria, Annual Report on the Department of Labour, Nigeria, for the Year 1943 (Lagos: Government Printers, 1945), 11.

93. Your Prodigal Sons to the Resident, Calabar Province, 24 March 1936, NAE, CALPROF 5/1/194.

94. Ekpenyong Etim Santa Isabel, 2 June 1936, NAE, CALPROF, 5/1/194.

95. Inpector de Trabajo, 20 June 1948, “'Informe: Finca de Don Antonio Fernandez y Cia.," AGA, C-81/08214, E-1.

96. DO, Calabar to the Resident, Calabar Province, 3 December 1932, NAE, CALPROF 5/1/192; British Labour Officer, Calabar to Comm'r of Labour, Lagos, 6 December 1943, NAE, CALPROF 5/1/193.

97. British VC to DO, Uyo, 17 February 1949, "Statement of Anele Nwosu of Ameke Owerri and Elijah Chiolu of Umuochita Diobu, Ohoada Division," NAE, CALPROF 7/1/464.

98. Wilson Bassey to British Labour Officer, Santa Isabel, 9 June 1946, NAE, CALPROF 17/1/279.

99. Orde-Brown, The African Labourer, 52.

100. Akinlolu Ake, "In Nigeria Parents warn your Children," News Chronicle, London, 11 September 1954, in RHL, MSS. Brit. Emp. S.24 J.50. 
101. Adam McKeown, "How the Box Became Black: Brokers and the Creation of the Free Migrant," Pacific Affairs 85, 1 (2012): 21-45, 21.

102. DO, Eket to Supt. of Police, Aba, 24 November 1938, NAE, CALPROF 5/1/194; DO, Eket to the Resident, Calabar Province, 16 January 1939, NAE, CALPROF 5/1/194.

103. Michael Offiong was a prominent name on an early list of "persons suspected of recruiting" when the traffic was mostly still being conducted on the backs of forged permits and colonial steamships. Comm'r of Police, Calabar to Agent, Elder Lines, Calabar, 4 June 1936, NAE, CALPROF 5/1/194; see Enrique Martino, "Clandestine Recruitment Networks in the Bight of Biafra: Fernando Pó's Answer to the Labour Question, 1926-1945," International Review of Social History 57, 20 (2012): 39-72, 55-58.

104. Administración Territorial, Santa Isabel, 8 December 1942, "Relacion de los reclutadores que salen para Calabar," AGA, C-81/15865, E-12; British VC, 28 February 1941, "Labour Conditions in Spanish Guinea, Appendix C," TNA, FO $371 / 26908$.

105. Orde-Brown, The African Labourer, 50, 54; Angel Yglesias de La Riva, Politica indígena en Guinea (Madrid: Instituto de Estudios Africanos, 1947), 219.

106. Nigeria, Annual Report on the Department of Labour, Nigeria, for the Year 1943 (Lagos: Government Printers, 1945), 11.

107. “The Fernando Po Slave Traffic," The Nigerian Eastern Mail, Calabar, 25 February 1939; David Aworawo, "Foreign Policy and the Travails of Nigerian Migrants in Equatorial Guinea, 1930-1980," Nigerian Journal of International Affairs 25, 2 (1999): 24-35, 26.

108. Supt. of Police, Calabar to Comm'r of Police, Lagos, 30 December 1938, NAE, CALPROF 5/1/194.

109. Labour Officer, Calabar to Comm'r of Labour, Lagos, 18 September 1943, NAE, CALPROF 5/1/193.

110. M. D. W. Jeffreys, "Books in Review; Review of Water Transport. Origins and Early Evolution. HORNELL, J. (Cambridge University Press: 1946)," African Studies 8, 2 (1949): 104-6, 106.

111. Labour Officer, Calabar to Comm'r of Labour, Lagos, 6 December 1943, NAE, CALPROF 5/1/193.

112. Comm'r of Police, Calabar to the Resident, Calabar Province, 8 August 1935, NAE, CALPROF 5/1/192.

113. Supt. of Police, Calabar to Comm'r of Police, Lagos, 30 December 1938, NAE, CALPROF 5/1/194; Labour Officer, Calabar, to Comm'r of Labour, Lagos, 6 December 1943, NAE, CALPROF 5/1/193.

114. Ugo Nwokeji, "The Slave Emancipation Problematic: Igbo Society and the Colonial Equation," Comparative Studies in Society and History 40, 2 (1998): 318-55; 337, 342; Afigbo, The Abolition of the Slave Trade, 106, 90.

115. Mbadiwe, "Nigerian Workers in Po," West African Pilot, Lagos, 26 August 1954; British VC to Supt. of Police, Calabar, 22 January 1945, NAE, CALPROF 17/1/277. 
116. S. Muyiwa to Comm'r of Police, Calabar, 24 May 1936, NAE, CALPROF 5/1/194.

117. British VC to Supt. of Police, Calabar, 25 November 1944, NAE, CALPROF, $17 / 1 / 277$. Oron's commercial boom in the early twentieth century sprang forth when direct links to the "cargo boats from Liverpool" were, literally, cementedthrough the mass requisitioning of forced labor to prepare the gravel for ports and drain the creeks, after which "the merchants of Oron stated that trade grew by leaps and bounds till" it "had risen to about three times that of Calabar." Percy Talbot, Life in Southern Nigeria: The Magic, Beliefs, and Customs of the Ibibio Tribe (London: Macmillan and Co., 1923), 256; Walter I. Ofonagoro, "An Aspect of British Colonial Policy in Southern Nigeria: The Problems of Forced Labour and Slavery, 1895-1928," in Studies in Southern Nigerian History, ed. Boniface Obichere (London: Frank Cass, 1982), 219-244, 237.

118. DO, Eket to the Resident, Calabar Province, 29 February 1936, NAE, EKETDIST 1/2/146; A. J. H. Latham, Old Calabar, 1600-1891: The Impact of the International Economy Upon a Traditional Society (Oxford: Oxford University Press, 1973), 89-90.

119. Chief Ntak Ikam Eba on behalf of Oron Native Authority Council to DO, Eket, 22 February 1938, NAE, CALPROF 3/1/1953.

120. J.W. Kicks-Dadzie to the Resident, Calabar Province, September 1939, "Confidential Report: Labour in Fernando Poo," NAE, CALPROF 5/1/195; Special Correspondent [Kicks-Dadzie], "Fernando Po Labour Conditions," The Nigerian Daily Times, Lagos, 13 July 1939.

121. Ewart Shepherd, "Nigerian Labourers in Fernando Po. Dr. Haden Guest Misinformed? Allegations of Slavery Cannot Be Substantiated," West Africa, London, 13 May 1939.

122. Dodds, July 1939, "Notes on Visit to West African District, February to June 1939," SOAS, M.M.S. MMS/Special Series/Notes and Transcripts/FBN 1, fiche 15-17; F.W. Dodds, "Nigerian Labourers in Fernando Po," West Africa, London, 24 June 1939.

123. Comm'r of Police, Buea to Senior Resident, Calabar Province, 31 January 1934, NAE, CALPROF 5/1/192; British VC to the Resident, Calabar Province, 30 November 1938, NAE, CALPROF 5/1/194.

124. Ekpe Eyo, Santa Isabel to Eyo Ubon, Afaha Atai, Uyo Division, Calabar Province, 2 September 1938, NAE CALPROF 5/1/194.

125. As evidenced by "the impunity of the lie" that was exempted "from punishment in Roman and ancient Germanic law," and for that matter Nigerian colonial law. Walter Benjamin, "Critique of Violence," from Selected Writings (Cambridge: Harvard University Press, 1996[1921]), 245.

126. Mbadiwe, "Nigerian Workers in Po," West African Pilot, Lagos, 26 August 1954.

127. J.W. Kicks-Dadzie to the Resident, Calabar Province, September 1939, "Confidential Report: Labour in Fernando Poo," NAE, CALPROF 5/1/195.

128. Ekpe Eyo, Santa Isabel to Eyo Ubon, Afaha Atai, Uyo Division, Calabar Province, 2 September 1938, NAE CALPROF 5/1/194. 
129. Governor's Deputy, Lagos to Sec. of State for the Colonies, London, $23 \mathrm{Au}-$ gust 1939, TNA, FO 371/23171.

130. Orde-Brown, The African Labourer, 70.

131. The contract defined the plantation worker as a "Bracero.- - He whose labour consists exclusively in contributing physical effort with the will and attention required to execute what is ordered." "Ordenacion del contrato de trabajo de la region ecuatorial," 24 May 1962, in Boletín Oficial de Guinea, 15 June 1962, Article 23. The contract was rarely formally subject to contestation; it was not there to generate a subset of archival genres-inspection tours, a minimally construed setting for actual consent and recourse to some sort of judicial machinery for redress or appeal. Such paperwork only started filling the colonial archive in the 1950s. The contract was not a communication; it was your name in a registry, with a copy of it handed over.

132. Alessandro Stanziani, "Beyond Colonialism: Servants, Wage Earners and Indentured Migrants in Rural France and on Reunion Island (c. 1750-1900)," Labor History 54, 1 (2013): 64-87, 71; Prabhu Mohapatra, "From Contract to Status? Or How Law Shaped Labour Relations in Colonial India 1780-1920," in India's Unfree Workforce: Of Bondage Old and New, ed. Jan Breman (New Delhi: Oxford University Press, 2009), 96-125, 120.

133. British VC, 28 February 1942, "Labour Conditions in Spanish Guinea," TNA, FO 371/26908; Osuntokun, Equatorial Guinea Nigerian Relations, 32.

134. GG, 25 June 1910, "Presentación trabajadores," in Agustín Miranda Junco, Leyes coloniales: legislación de los territorios españoles del Golfo de Guinea (Madrid: Imprenta Sucesores de Rivadeneyra, 1945), 401.

135. The obligatory contracts on Fernando Pó were rationed down from the five to eight years of local post-emancipation apprenticeships and the imported template of Chinese indentured workers in Cuba. Sundiata, "The Rise and Decline of Kru Power," 29; García Cantús, “Fernando Poo," 515; Bartolome Clavero, "Bioko, 1837-1876: constitucionalismo de Europa en África, derecho internacional consuetudinario del trabajo mediante," Quaderni Fiorentini per la Storia del Pensiero Giuridico Moderno 35 (2006), 429-546. The minimum length came to be two years, but the length was a barely negotiated extortion: "Ali, a native of Lagos," "complains that he was found by a man called Bruce in Accra, who told him that he was taking him to Calabar" to "work cargo." Along with small waves of new arrivals on steamers transiting Fernando Pó, they were "disembarked" and "taken before the Curador" who "told that if they did not make a contract for five years he would send them to gaol [jail]. They then made a contract for three years." British VC to Curaduria, 10 June 1913, TNA, FO 367/353.

136. Northrup, Indentured Labor in the Age of Imperialism, 6.

137. Nigerian Secretariat, Lagos, 1953, "Memorandum", RHL, 600.18 s. 21/XI (10). "The ordinance was specifically targeted at Spanish Guinea's labor trade, the notoriety of which was becoming well known in the 1920s"; Aworawo, "Decisive Thaw," 93. 
138. Jairus Banaji, "The Fictions of Free Labour: Contract, Coercion, and SoCalled Unfree Labour," Historical Materialism 11, 3 (2003): 69-95, 74; Jairus Banaji, "Modernizing the Historiography of Rural Labour: An Unwritten Agenda," in Companion to Historiography, ed. Michael Bentley (London: Routledge, 2006), 88-104, 89; see also Martin J. Murray, “'Blackbirding' at 'Crooks' Corner': Illicit Labour Recruiting in the Northeastern Transvaal, 1910-1940," Journal of Southern African Studies 21, 3 (1995): 373-397, 377, 397.

139. Robert J. Steinfeld, Coercion, Contract, and Free Labor in the Nineteenth Century (New York: Cambridge University Press, 2001), 8.

140. Laurence Brown, “'A Most Irregular Traffic': The Oceanic Passages of the Melanesian Labor Trade," in Many Middle Passages: Forced Migration and the Making of the Modern World, eds. Emma Christopher, Marcus Rediker, and Cassandra Pybus (Berkeley: University of California Press, 2007), 184-203, 185.

141. Orde-Brown, The African Labourer, 74; For explanations on slang terms, see Linebaugh and Rediker, The Many-Headed Hydra, 110.

142. Murray, “'Blackbirding' at 'Crooks' Corner'," 382, 389, 380; Alan Jeeves, "Over-Reach: The South African Gold Mines and the Struggle for the Labour of Zambesia, 1890-1920," Canadian Journal of African Studies 17, 3 (1983): 393-412, 404, 407; Andrew MacDonald, "Forging the Frontiers: Travelers and Documents on the South Africa-Mozambique Border, 1890s-1940s," Kronos 40, 1 (2014): 154-77, 157; Patrick Harries, Work, Culture, and Identity: Migrant Laborers in Mozambique and South Africa, c.1860-1910 (Portsmouth: Heinemann, 1993), 115; Frederick Cooper, Decolonization and African Society: The Labor Question in French and British Africa (Cambridge: Cambridge University Press, 1996), 44

143. Martin A. Klein, Historical Dictionary of Slavery and Abolition (Lanham: Scarecrow Press, 2002), 76; Wareing, " 'Violently Taken Away or Cheatingly Duckoyed'," 1; Brown, "AA Most Irregular Traffic'," 194; Miers and Roberts, "The End of Slavery in Africa," 21; Ravi Raman, Global Capital and Peripheral Labour: The History and Political Economy of Plantation Workers in India (London: Routledge, 2010), 100.

144. The Global Commission of International Migration rediscovers the crimp: "It has become clear to the Commission some of the individuals and enterprises involved in the recruitment process are guilty of misleading and cheating the migrants they engage, usually by providing them with false information, promises or expectations." Global Commission of International Migration, Migration in an Interconnected World: New Directions for Action (Geneva: GCIM, 2005), 70. See especially the conclusion of Adam M. McKeown, Melancholy Order: Asian Migration and the Globalization of Borders (New York: Columbia University Press, 2013), 349-369.

145. Julia O'Connell Davidson, Modern Slavery: The Margins of Freedom (New York: Palgrave Macmillan, 2015), 111-112. On the non-possibility of exiting a contract as the common defining marker of unfree waged labor, see Tom Brass, "Why Unfree Labour Is Not 'So-Called': The Fictions of Jairus Banaji," Journal of Peasant Studies 31, 1 (2003): 101-36. 